\title{
Implication of heat shock proteins in rotavirus entry into Reh cells
}

\author{
J. RICO ${ }^{\dagger}$, C. PEREZ, R. GUERRERO, J. HERNANDEZ, C. GUERRERO*, O. ACOSTA
}

Department of Physiological Sciences, Faculty of Medicine, Universidad Nacional de Colombia, Bogota, D.C., Colombia

Received July 26, 2019; revised March 12, 2020; accepted August 18, 2020

\begin{abstract}
Summary. - The mechanisms of rotavirus entry into the target cell are described as a multi-step event in which the virions are bound to sialic acid (SA), followed by interaction with heat shock cognate protein 70 (Hsc70), some integrins and protein disulfide isomerase (PDI). However, the cell surface receptor molecules facilitating the entry of tumor cell-adapted rotavirus are not completely characterized. Using infection blocking assays with antibodies to some heat shock proteins (HSPs) and also some inhibitors of these cellular proteins, we were able to identify the cell surface Hsp90, Hsp70, Hsc70, Hsp60, Hsp40, PDI and integrin $\beta 3$ as receptors of tumor cell-adapted rotavirus in Reh cells. Furthermore, the results also indicated that these rotavirus receptors are associated with lipid microdomains (rafts). Our findings provide evidence that rotavirus tropism for these human acute lymphocytic leukemia cells is explained by the relatively high expression of some HSPs in rafts. The results shown here encourage further research aim at evaluating the potential use of rotaviruses as an oncolytic agent for the treatment of some cancers.
\end{abstract}

Keywords: heat shock proteins; rotavirus; cell receptor; cancer; oncolytic virus

\section{Introduction}

Rotaviruses, as members of the family Reoviridae, infect children under five years, producing severe and dehydrating diarrhea that causes annually more than 200 000 deaths worldwide, mostly in developing countries (Crawford et al., 2017). Virus tropism refers to the types of organism, tissues, and cells that a virus can infect (Fields et al., 2007). Replication of animal viruses begins with the attachment of virions to some cellular molecules which are critical for maintaining the tropism of the virus. However, enveloped and non-enveloped viruses differ in the way they deliver their genome into the target cell. In the case of rotavirus, a non-enveloped virus, the mecha-

"Corresponding author. E-mail: caguerrerof@unal.edu.co; phone: +57-1-3165000 Ext. 15053 . $^{+} \mathrm{JR}$ died shortly after concluding this study.

Abbreviations: $\mathrm{Hsc70}=$ heat shock cognate protein 70; HSP/Hsp = heat shock protein; $\mathrm{MFI}=$ median fluorescence intensity; PDI = protein disulfide isomerase; $\mathrm{SA}$ = sialic acid; $\mathrm{SP}$ = structural protein; TLP = triple-layered particles nisms involved in the attachment to MA104 cells are not completely understood. A multi-step event for attachment has been suggested in which virions are first bound to cell surface $\mathrm{N}$-acetyl neuraminic (sialic) acid (SA), followed by the binding to heat shock cognate protein 70 (Hsc70) (Lopez and Arias, 2006; Arias et al., 2015), some integrins (Guerrero et al., 2000; Zárate et al., 2000, 2004; Graham et al., 2003), and protein disulfide isomerase (PDI) (Calderon et al., 2012). These sequential interactions between the virions and cell surface molecules are mediated by the rotavirus structural proteins VP4 and VP7 and the entrance into the cell involves different types of endocytosis and release into the cytosolic space, depending on the viral strain (Arias et al., 2015; Guerrero and Acosta, 2016). Rotaviruses have been found to interact with the SA-containing ganglioside GM1, integrin subunits $\alpha 2$ and $\beta 3$, and the heat shock cognate protein 70 (Hsc70), which are associated in cholesterol-enriched lipid microdomains (rafts) from MA104 cells (Isa et al., 2004).

Heat shock proteins (HSPs) are a family of chaperones involved in the response to several environmental and physiologically stressful conditions. HSPs play a critical 
role in re-establishing the native conformation of proteins to maintain their functional state in both physiological and stress conditions. According to their molecular sizes, HSPs have been classified into six families: small HSPs (Hsp27), Hsp40 family, chaperonin family (Hsp60), Hsp70 family, Hsp90 family, and large family of HSPs (Hsp110 and glucose-regulated protein 170, GRP170) (Wang et al., 2014; Wu et al., 2017). Normal cells respond to stress by increasing the expression of HSPs. However, the dysregulated expression of HSPs is a contributor to the development of some diseases, including cancer (Chatterjee and Burns, 2017). Most of the crucial proteins involved in the tumoral phenotype require increased expression of the HSPs for their re-folding, stabilization, and activation (Chatterjee and Burns, 2017). Inhibition of HSPs has been highlighted as a tool for targeting several proteins involved in maintaining the tumor progression (Wang et al., 2014; Chatterjee and Burns, 2017).

Some small molecule inhibitors have been used to inhibit HSPs such as quercetin, RP10, and protein aptamers for Hsp27 (Gibert et al., 2011; Heinrich et al., 2011; Chen et al., 2012). Myrtucommulone (Wiechmann et al., 2017), bortezomib (Chang et al., 2012), and sinularin (Su et al., 2012) have been shown to inhibit Hsp60 in malignant cells. Inhibition of Hsp70 has been obtained using small molecule inhibitors (pifithrin- $\mu, 15$-deoxyspergualin, MAL3-101, VER-155008, MKT-077, and quercetin) (Nadeau et al., 1994; Britten et al., 2000; Rodina et al., 2007; Massey et al., 2010; Kaiser et al., 2011; Yang and Tohda, 2018), protein aptamers (A17) (Seigneuric et al., 2011), and antibody treatment (cmHsp70.1) (Stangl et al., 2011). Hsp90 has been inhibited with geldanamycin (Houry, 2014), radicicol (Soga et al., 2003), 17-AAG (Banerji et al., 2005), 17-DMAG (Lancet et al., 2010), IPI-504 (Hanson and Vesole, 2009), NVP-AUY922 (Ueno et al., 2012), and AT13387 (Graham et al., 2012). Other Hsp90 inhibitors include ganetespib (STA9090), CNF-2024/BIIB021, Debio 0932, PU-H71, SNX-5422 and TAS-116 (Chatterjee and Burns 2017). HSF1, a member of the large HSP family, has been shown to be inhibited by quercetin (Nagai et al., 1995), KNK437 (Ohnishi et al., 2004), triptolide (Zhang et al., 2018), KRIBB11 (Yoon et al., 2011) and rocaglates (Santagata et al., 2013). The DNA binding ability of HSF1 has been reported to be inhibited by an RNA aptamer (Salamanca et al., 2014).

The protein disulfide isomerase family encompasses many multifunctional endoplasmic reticulum enzymes that are implicated in the catalysis of thiol-disulfide exchange reactions and some of them are also present in the cell surface (Calderon et al., 2012). It has been recently shown that some PDI members participate in several human disorders, including cancer (Lee and Lee, 2017). PDI members are implicated in a variety of cancers in terms of promoting proliferation, survival, and metastasis of tumor cells (Zong et al., 2012; Ramos et al., 2015; Lee and Lee, 2017). Overexpression of PDI proteins, such as ERp57, ERp72, and P5 has been found in breast, thyroid, rectal, gastric and liver cancers (Xu et al., 2011; Ramos et al., 2015; Uyy et al., 2016). Integrins are transmembrane glycoproteins consisting of an $\alpha$ subunit and a $\beta$ subunit. $\beta 1$ and $\beta 3$ integrins are implicated in the progression of different processes associated with cancer, such as the initiation, proliferation, survival, migration, and invasion (Pan et al.,, 2018). Since the expression of the $\beta 1$ and $\beta 3$ integrins is involved in tumor progression, these proteins have been addressed as potential therapeutic targets for inhibiting tumor growth (Pan et al., 2018). In this context, antagonists of $\beta 1$ or $\beta 3$ integrin have been effectively used for inhibiting tumor growth (Robinson and Hodivala-Dilke, 2011; Besse et al., 2012). In clinical trials, cilengitide, an inhibitor of $\alpha v \beta 3$ integrin, was shown to lengthen the survival time of patients affected with some cancers (Vansteenkiste et al., 2015). In addition, monoclonal antibodies that block av $\beta 3$ integrin function have demonstrated anti-angiogenic activity, tumor growth inhibition and reduction of metastasis rates in preclinical trials (Mulgrew et al., 2006). Monoclonal antibodies to $\alpha 5 \beta 1$ integrin function have also proved to be a promising therapeutic strategy for treating malignant tumors in preclinical trials (Besse et al., 2012).

Since oncolytic viruses have emerged as a therapeutic approach to effectively target and destroy cancer cells (Lin et al., 2018), and a variety of tumor cells exhibit an overexpression of HSPs, PDI and $\beta 3$ integrin we took advantage of these two facts and analyzed the infection of Reh cells, derived from human acute lymphocytic leukemia, with tumor cell-adapted rotavirus isolates. The specific tropism of oncolytic viruses for malignant cells has made them a promising tool in cancer treatment without significant adverse effects (Sivanandam et al., 2019). In contrast to conventional chemotherapy and radiotherapy, the oncolytic viruses can offer additional benefits in terms of the induction of effector anti-tumor immune response (Raja et al., 2018). In the present work, we show that tumor celladapted rotavirus isolates were able to successfully infect Reh cells using the cell surface Hsp90, Hsp70, Hsc70, Hsp60, Hsp40, PDI and integrin $\beta 3$ as receptors, which were found to be associated in lipid rafts.

\section{Materials and Methods}

Cells and viruses. Reh cells (ATCC ${ }^{\circ} \mathrm{CRL}-8286^{\mathrm{TM}}$ ) derived from human acute lymphocytic leukemia (non-T; non-B) were kindly provided by Dr. J. P. Vernot (Faculty of Medicine, Universidad Nacional de Colombia) and grown in RPMI 1640 media (SigmaAldrich, USA). Tumor cell-adapted rotavirus strains TRUYO, 
WWM, WTEW, Wt1-5, and ECwt-o were obtained as described previously (Guerrero et al., 2016).

Virus purification. Viruses were purified from tumor cells (Guerrero et al., 2016) by two cycles of freezing and thawing in tris-buffered saline (TBS) followed by emulsification with Freon 113 and ultracentrifugation in sucrose-CsCl gradients as described previously (Gualtero et al., 2007). The triple-layered and double-layered particles (TLPs and DLPs) were separately collected and further subjected to an additional cycle of sucrose- $\mathrm{CsCl}$ gradient centrifugation. Finally, virus particles were concentrated by ultracentrifugation and resuspended in TNC buffer (10 mM Tris- $\mathrm{HCl}, \mathrm{pH} 7.4,150 \mathrm{mM} \mathrm{NaCl}, 1 \mathrm{mM} \mathrm{MgCl}$, and $5 \mathrm{mM} \mathrm{CaCl}_{2}$ ).

Cell infection. Cells $\left(5 \times 10^{4}\right)$ in $50 \mu \mathrm{l}$ of RPMI 1640 without fetal bovine serum (FBS) were separately inoculated with rotavirus isolates (MOI 0.8) and activated with trypsin at $10 \mathrm{mg} / \mathrm{ml}$ for $30 \mathrm{~min}$ at $37^{\circ} \mathrm{C}$ (Arias et al., 1996). The inoculated cells were incubated for $12 \mathrm{~h}$ at $37^{\circ} \mathrm{C}$ in a chamber with a humidified atmosphere containing $5 \% \mathrm{CO}_{2}$. Cells were harvested and lysed by freezing and thawing. The infectious titer for each rotavirus yield was determined by immunochemistry assay.

Immunochemistry assay. Cells infected with rotavirus isolates in 96-well culture plates were fixed with $4 \%$ paraformaldehyde (PFA) for $30 \mathrm{~min}$ at room temperature (RT) followed by treatment with ice-cold methanol. Rabbit hyperimmune serum against rotavirus particles (1:2,000; prepared in our facilities) were added to PBS-washed cells and incubated for $1 \mathrm{~h}$ at $37^{\circ} \mathrm{C}$. After washing with PBS, cells were incubated with secondary HRP-conjugated goat anti-rabbit antibodies $(0.133 \mu \mathrm{g} / \mathrm{ml}$, Santa Cruz, USA) for $1 \mathrm{~h}$ at $37^{\circ} \mathrm{C}$. Cells positive for rotavirus structural antigens were visualized with 3-amino-9-ethylcarbazole (AEC; Sigma-Aldrich, USA) substrate $(0.25 \mathrm{mg} / \mathrm{ml})$ in $50 \mathrm{mM}$ sodium acetate buffer ( $\mathrm{pH} 5.0$ ), containing $0.04 \% \mathrm{H}_{2} \mathrm{O}_{2}$. The mean percentage of infected cells was determined using a conventional light microscope by taking at least 10 representative photographs.

Cell viability. Cell viability of Reh cell suspensions was determined using the trypan blue exclusion test (Strober, 2001). The cell viability test was used to determine the maximum concentrations of antibodies to HSPs and HSP inhibitors tolerated by cells without affecting viability. Cell viability was also determined with resazurin (O'Brien et al., 2000) by treating the cells $\left(6.6 \times 10^{4}\right)$ in a 96-well culture plate with $100 \mathrm{ml}$ of culture medium containing $0.4 \mathrm{mM}$ resazurin (Amresco, USA). After incubation at $37^{\circ} \mathrm{C}$ for $4 \mathrm{~h}$, the fluorescence of the product (resorufin) was measured using a Cytation 3 Cell imaging multimode reader (Bio-Tek, USA) at excitation wavelength of $535 \mathrm{~nm}$ and emission wavelength of $595 \mathrm{~nm}$.

Isolation of cell membrane-enriched fractions. The isolation of the cell membrane enriched fractions was conducted essentially as previously described (Lin et al., 1987). PBS-washed cells $\left(1 \times 10^{8}\right)$ were treated with hypotonic buffer $(5 \mathrm{mM}$ Hepes, pH 7.4, $50 \mathrm{mM}$ sucrose) and lysed using a manual glass homogenizer for $5 \mathrm{~min}$. To final concertation of $10 \mathrm{mM} \mathrm{CaCl}_{2}$ was added to the homogenates and centrifuged at 3,500 $\mathrm{xg}$ for 5 $\min$ at $4^{\circ} \mathrm{C}$. The supernatant was recovered and submitted to further centrifugation at $59,800 \mathrm{xg}$ for $30 \mathrm{~min}$ at $4^{\circ} \mathrm{C}$. The supernatant was discarded, and the pellet resuspended in sterile PBS containing $0.02 \%$ sodium azide and kept at $4^{\circ} \mathrm{C}$ until use for maximum of $24 \mathrm{~h}$.

ELISA. Commercial antibodies and guinea pig or rabbit antibodies obtained in our facilities were previously tested in ELISA for the absence of cross-reactivity among them and the absence of cross-reactivity with rotavirus or the cellular proteins studied. To detect HSPs forming complexes with integrin $\beta 3$, PDI and Hsc70, cell membrane-enriched fractions were solubilized with RIPA buffer ( $150 \mathrm{mM} \mathrm{NaCl}, 1 \% \mathrm{NP}-40,0.5 \%$ DOC, $0.1 \%$ SDS, 50 mM Tris-HCl, pH 8.0) and applied into ELISA plates previously coated with rabbit antibodies against integrin $\beta 3$, PDI or Hsc70 (Santa Cruz) and blocked with $1 \%$ casein. After wash with PBS- $0.05 \%$ Tween 20 (PBS-T), goat antibodies against Hsp90, Hsp70, Hsp60, Hsp40, integrin $\beta 3$, PDI and Hsc70 (0.2 $\mu \mathrm{g} / \mathrm{ml}$ each, Santa Cruz) were separately added and incubated at $37^{\circ} \mathrm{C}$ for $1 \mathrm{~h}$. Following three washes with PBS-T, secondary HRP-conjugated donkey anti-goat IgG $(0.133 \mu \mathrm{g} / \mathrm{ml})$ was added and maintained for $1 \mathrm{~h}$ at $37^{\circ} \mathrm{C}$. The reaction was visualized with OPD (Pierce, Thermo Scientific, USA) in $100 \mathrm{mM}$ citrate buffer (pH 5) and detected at $492 \mathrm{~nm}$. Incubation with all antibodies without solubilized cell membrane-enriched fractions was used as a control and data were presented as delta OD. In parallel, cell membrane-enriched fractions were separately incubated with the five rotavirus isolates for $1 \mathrm{~h}$ at $37^{\circ} \mathrm{C}$. The cells were solubilized in RIPA buffer for $30 \mathrm{~min}$ at $37^{\circ} \mathrm{C}$ and incubated in ELISA plates coated with guinea pig capture antibodies against rotavirus structural proteins (SP). Goat antibodies against Hsp90, Hsp70, Hsp60, Hsp40, Hsc70, PDI or integrin $\beta 3$, were separately added as primary antibodies, while HRP-conjugated anti-goat IgG was used as secondary antibody. Visualization of the reaction with OPD was done as described above.

Isolation of lipid microdomains-rafts. Cells $\left(1 \times 10^{8}\right)$ in RPMI 1640 were treated or left un-treated with $10 \mathrm{mM}$ methyl- $\beta$ cyclodextrin (Sigma, USA) for $1 \mathrm{~h}$ at $37^{\circ} \mathrm{C}$ and then washed with PBS. Cells were resuspended in lysis buffer $(250 \mathrm{ml})$ consisting of $50 \mathrm{mM}$ Tris- $\mathrm{HCl}$, pH 7.5, $150 \mathrm{mM} \mathrm{NaCl}, 2$ mM EDTA, 2 mM DTT, $1 \%$ Triton X-100 and $2 \mathrm{mM}$ PMSF and kept at $4^{\circ} \mathrm{C}$ for $20 \mathrm{~min}$. The cell lysates were applied to $40 \%$ sucrose by adding an equal volume of $80 \%$ sucrose in lysis buffer and then overlaid with a $5-30 \%$ continuous sucrose gradient and centrifuged at $120000 \mathrm{x}$ $\mathrm{g}$ for $4 \mathrm{~h}$ at $4^{\circ} \mathrm{C}$. Fractions were collected from the top of the gradient and then treated with $1 \%$ Triton X-100 for $30 \mathrm{~min}$ at $37^{\circ} \mathrm{C}$. Solubilized fractions were placed into ELISA plates coated with anti-integrin $\beta 3$ antibodies and blocked with $1 \%$ casein. The PBST-washed plates were incubated separately with primary goat antibodies to Hsp90, Hsp70, Hsp60 or Hsp40, Hsc70 or integrin $\beta 3$ for $1 \mathrm{~h}$ at $37^{\circ} \mathrm{C}$ and then washed three times with PBS-T. HRPconjugated anti-goat IgG was used as a secondary antibody. The reaction was visualized and analyzed as described above. 
Inhibition of virus binding. Reh cells $\left(1 \times 10^{7}\right)$ in RPMI 1640 without FBS were incubated with rabbit $F\left(\mathrm{ab}^{\prime}\right) 2$ fragments against synthetic peptides derived from Hsp90, Hsp70, Hsp60 or Hsp40. The peptide sequences used to induce the antibodies were as follows: Hsp90 (620-RDNSTMGYMAAK KHLEINPDHS-641); three peptides of Hsp70 (705-QIQQYM KIISSFKNKEDQYDHLD-727); (646-NSFTLKLEDTENWLY EDGDQPKQ-668); (741-AMEWMNNKLNLQNKQSLTMDP-761); Hsp60 (393-RLAKLSDGVAVLKVGGTSDVEVN-415); Hsp40 (251-GSDVIYPARISLREALCGCTVNV-273).F(ab')2 fragments were added at serial dilutions (1:40,1:80,1:160,1:320;1:640 and 1:1,280) and incubated for $1 \mathrm{~h}$ at $37^{\circ} \mathrm{C}$. Unbound $\mathrm{F}\left(\mathrm{ab}^{\prime}\right) 2$ fragments were removed by washing with cold PBS and collected by centrifugation at $600 \mathrm{xg}$. The cells were separately inoculated with $1 \mathrm{ml}$ of PBS at $4^{\circ} \mathrm{C}$ containing the respective rotavirus isolate at MOI 2 and incubated for $45 \mathrm{~min}$ at $4^{\circ} \mathrm{C}$. Cells were washed and lysed with RIPA buffer with $5 \mathrm{mM}$ PMSF for $1 \mathrm{~h}$ at $37^{\circ} \mathrm{C}$. In parallel, cell lysates were separately added into ELISA plates coated with antiSP rabbit capture antibodies and blocked with $1 \%$ casein. After incubation for $1 \mathrm{~h}$ at $37^{\circ} \mathrm{C}$ and washing with PBS, goat primary antibody to rotavirus $\mathrm{SP}$ was added for $1 \mathrm{~h}$ at $37^{\circ} \mathrm{C}$. Following PBS washing, secondary HRP-conjugated anti-goat antibody (0.133 $\mu \mathrm{g} / \mathrm{ml}$ ) was added and incubated for $1 \mathrm{~h}$ at $37^{\circ} \mathrm{C}$. The reaction was developed with OPD substrate and analyzed as indicated above.

Immuno-dot blot assay. Suspensions of trypsin-activated rotavirus isolate Wt1-5 (20 $\mu$ l, MOI 3) were separately added onto PVDF membrane discs and incubated for $1 \mathrm{~h}$ at $37^{\circ} \mathrm{C}$. Discs were blocked with 5\% skimmed milk in PBS for $1 \mathrm{~h}$ at $37^{\circ} \mathrm{C}$ under continuous agitation. In parallel, dot blots were separately incubated with rHsp90 or $\mathrm{rHsp} 70(30,15,7.5$ and $3.75 \mu \mathrm{g} / \mathrm{ml}$ ) in 96 -well culture plates at $4^{\circ} \mathrm{C}$ overnight. Dot blots were washed three times with PBS under continuous agitation and then incubated with rabbit serum against Hsp90 or Hsp70 diluted 1:2,000 in PBS containing $0.5 \%$ BSA for $1 \mathrm{~h}$ at $37^{\circ} \mathrm{C}$. After washing three times with PBS, secondary HRP-conjugated goat anti-rabbit antibody $(0.4 \mathrm{~g} / \mathrm{ml}$, Santa Cruz $)$ was added for $1 \mathrm{~h}$ at $37^{\circ} \mathrm{C}$. The reaction was detected using AEC substrate as indicated above. Conversely, $20 \mu \mathrm{l}$ of rHsp90 or rHsp70 at $150 \mu \mathrm{g} /$ $\mathrm{ml}$ concentration were applied on dot blots and blocked with $5 \%$ skimmed milk for $1 \mathrm{~h}$ at $37^{\circ} \mathrm{C}$ under continuous agitation. The dot blots were separately incubated with rotavirus suspensions (50 $\mu \mathrm{l}, \mathrm{MOI} 3)$ in 96 -well culture plates at $4^{\circ} \mathrm{C}$ overnight. After PBS washing, the dot blots were incubated with anti-SP rabbit antibodies at $4^{\circ} \mathrm{C}$ overnight. Secondary HRP-conjugated goat anti-rabbit antibody was added and incubated for $1 \mathrm{~h}$ at $37^{\circ} \mathrm{C}$. The reaction was visualized with AEC substrate as indicated above in the immunochemistry assay.

Immunoprecipitation assay. Cell membrane-enriched fractions were washed with PBS and separately incubated with the trypsin-activated rotavirus isolates in PBS and incubated for $45 \mathrm{~min}$ at $37^{\circ} \mathrm{C}$. The preparations were treated with RIPA buffer with $5 \mathrm{mM}$ PMSF for $30 \mathrm{~min}$ at $37^{\circ} \mathrm{C}$. The solubilized membranes $(100 \mu \mathrm{l})$ were incubated with Protein A-agarose beads ( $5 \mu 1,90-180 \mu \mathrm{m}$; Bio-Rad, USA) that had been coated with anti-SP antibodies blocked with $0.5 \%$ casein. The mixture was continuously agitated for $30 \mathrm{~min}$ at RT and afterwards the beads were collected by centrifugation and washed three times with PBS. The beads were boiled in Laemmli buffer and subjected SDS-PAGE followed by Western blot analysis using a mixture of goat primary antibodies to Hsp90, Hsp70, Hsp60 and Hsp40 $(0.2 \mu \mathrm{g} / \mathrm{ml}$, Santa Cruz) or, alternatively, goat primary anti-SP antibodies. Secondary HRP-conjugated donkey anti-goat IgG was added and incubated for $1 \mathrm{~h}$ at $37^{\circ} \mathrm{C}$. The reaction was developed with Western blotting luminol reagent (Invitrogen, USA). Parallel analysis was conducted simultaneously with beads without antibodies as a negative control. As an alternative to previous immunoprecipitation approach, cells $\left(1 \times 10^{7}\right)$ were washed with PBS, resuspended in $1 \mathrm{ml}$ of NHS-SS-Biotin: succinimidyl-2-(biotinamido)-ethyl-1,3'-dithiopropionate (1 mg/ $\mathrm{ml}$; Pierce, USA) and incubated for $30 \mathrm{~min}$ at $4^{\circ} \mathrm{C}$. The cells were washed in PBS containing $100 \mathrm{mM}$ glycine for $30 \mathrm{~min}$ at $4^{\circ} \mathrm{C}$ before inoculation with each of five trypsin-activated rotavirus isolates at MOI 4 and incubated for $30 \mathrm{~min}$ at $4^{\circ} \mathrm{C}$. Unbound virus was removed by washing the cells with MEM. The cells were washed with PBS and lysed with RIPA buffer before the addition of Protein A-agarose beads coated with rabbit anti-SP antibodies. The mixture was continuously agitated for $30 \mathrm{~min}$ at RT and processed as in SDS-PAGE/Western blot analysis. The PVDF membrane was blocked with $5 \%$ casein and incubated with HRP-streptavidin conjugate for $1 \mathrm{~h}$ at $37^{\circ} \mathrm{C}$. The reaction was developed as indicated above.

Virus overlay protein binding assay (VOPBA). Cells ( $\left.1 \times 10^{8}\right)$ were lysed by vortexing in Laemmli buffer without reducing agent at RT. After centrifugation at $13,000 \times \mathrm{g}$ for $10 \mathrm{~min}$, the proteins in the resultant supernatant were analyzed by SDSPAGE/Western blot. One casein-blocked PVDF membrane strip was incubated with trypsin-activated rotavirus isolate Wt1-5 at $4^{\circ} \mathrm{C}$ overnight and washed once with PBS before fixation with glutaraldehyde ( $2.5 \%$ final concentration) for $30 \mathrm{~min}$ at $37^{\circ} \mathrm{C}$. After washing with PBS, the membrane strip was incubated with rabbit primary anti-SP antibodies for $1 \mathrm{~h}$ at $37^{\circ} \mathrm{C}$. After washing with $\mathrm{PBS}$, secondary HRP-conjugated goat anti-rabbit antibody was added and incubated for $1 \mathrm{~h}$ at $37^{\circ} \mathrm{C}(0.2 \mu \mathrm{g} / \mathrm{ml})$. The reaction was visualized using Western blotting luminol kit (Invitrogen). A parallel membrane strip containing the same sample was probed with a mixture of goat antibodies to Hsp90, Hsp70, Hsp60 and Hsp40 and treated in the same way as the previous membrane strip, except that HRP-conjugated donkey anti-goat secondary antibody was used.

Infection blocking assay with HSP antibodies. Rabbit sera directed to synthetic peptides derived from Hsp90, Hsp70, Hsp60, and Hsp40 were serially diluted in MEM without FBS and added to cells in 96-well culture plates for $1 \mathrm{~h}$ at $37^{\circ} \mathrm{C}$. The cells were washed with MEM (Sigma-Aldrich, USA) without FBS and placed on ice for $15 \mathrm{~min}$ before inoculation with each rotavirus isolate at MOI 0.8 and incubated for $45 \mathrm{~min}$ at $4^{\circ} \mathrm{C}$. 
Unbound virus was removed by washing with PBS and the cells were incubated for $12 \mathrm{~h}$ at $37^{\circ} \mathrm{C}$ before the immunochemistry analysis to determine the percentage of infected cells. Alternatively, cells $\left(2 \times 10^{5}\right)$ in 48-well culture plates were incubated with goat antibodies ( 4 or $0.4 \mu \mathrm{g} / \mathrm{ml}$ ) to Hsp90, Hsp70, Hsp60, Hsp40, Hsc70, integrin $\beta 3$ or PDI or with a mixture of these antibodies $(0.4 \mu \mathrm{g} / \mathrm{ml}$ each) in PBS with $1 \%$ BSA. After incubation for $1 \mathrm{~h}$ at $37^{\circ} \mathrm{C}$, the cells were washed twice with PBS and then inoculated with the rotavirus isolate Wt1-5. The cells were collected after incubation for $24 \mathrm{~h}$ at $37^{\circ} \mathrm{C}$ and fixed in $4 \% \mathrm{PFA}$ in PBS for $30 \mathrm{~min}$ at RT. The PBS-washed cells were permeabilized with $0.5 \%$ Triton X-100 for $5 \mathrm{~min}$ at RT and washed twice with PBS before treatment with $50 \mathrm{mM}$ ammonium chloride and 100 $\mathrm{mM}$ glycine in PBS for $30 \mathrm{~min}$ at RT. Following PBS washing, rabbit serum against rotavirus SP was added and incubated for $1 \mathrm{~h}$ at $37^{\circ} \mathrm{C}$ followed by incubation with FITC-conjugated goat anti-rabbit secondary antibody (Santa Cruz) for $30 \mathrm{~min}$ at $37^{\circ} \mathrm{C}$ in the dark. The fluorescence was detected with a flow cytometer FACSCanto II (Becton Dickinson, USA). The analysis was performed using FlowJo vX.0.7 (tree Star) or BD FACSDiva software. Non-reactive isotype antibodies were used as a negative control to set the quadrant gates. Fluorescence data were expressed as median fluorescence intensity (MFI). Non-infected cells were also used as controls.

Inhibition of HSP activity. Cells were incubated with Hsp90 inhibitors 17AAG (80,40,20 and $10 \mathrm{nM})$ (Kao, 2016), NVP-AUY922 (16, 8, 4 and $2 \mathrm{nM})$ (Rui, 2015), radicicol (100, 50, 25 and $7.5 \mathrm{nM})$ (Gadelle, 2005), Hsp70 inhibitors VER-155008 (80, 40, 20 and $10 \mathrm{nM})$ (Schlecht, 2013), quercetin $(600,300,150$ and $75 \mu \mathrm{M})$ (Rong, 2000) for $1 \mathrm{~h}$ at $37^{\circ} \mathrm{C}$. Cells were inoculated with rotavirus isolates at MOI 0.8 and incubated for $45 \mathrm{~min}$ at $4^{\circ} \mathrm{C}$. The cells were immediately brought to $37^{\circ} \mathrm{C}$ for $12 \mathrm{~h}$ and then fixed with $4 \%$ PFA before the immunocytochemistry analysis to determine the percentage of infected cells. Quercetin $(300 \mu \mathrm{M})$ was also applied to cells after being subjected to $43^{\circ} \mathrm{C}$ for $30 \mathrm{~min}$ before inoculation with rotavirus isolates WTEW or Wt1-5. Cells without heat shock were used as controls.

Flow cytometry. Cells $\left(7 \times 10^{6}\right)$ in logarithmic growth phase were fixed with $4 \%$ PFA and washed twice with PBS before treatment with $50 \mathrm{mM}$ ammonium chloride and $100 \mathrm{mM}$ glycine for $30 \mathrm{~min}$ at RT. The cells were incubated with goat antibodies directed to Hsp90, Hsp70, Hsp60, Hsp40, Hsc70, integrin $\beta 3$ or PDI in PBS with $1 \% B S A$ for $1 \mathrm{~h}$ a $37^{\circ} \mathrm{C}$. The PBS-washed cells were incubated with FITC-conjugated rabbit anti-goat secondary antibodies (Santa Cruz, USA) for $1 \mathrm{~h}$ at $37^{\circ} \mathrm{C}$ and then washed with PBS before being analyzed by flow cytometer BD FACSCanto II as indicated above.

Pre-treatment of rotavirus isolates with recombinant HSPs. TLPs from rotavirus isolates TRUYO, WWM, WTEW, Wt1- 5 or ECwt-o infected at MOI 0.8 were treated with serial concentrations (3.125-100 ng/ml) of rHsp90 or rHsp70 in PBS for $12 \mathrm{~h}$ at $4^{\circ} \mathrm{C}$. The resultant complex was added to cells, incubated for $12 \mathrm{~h}$ at $37^{\circ} \mathrm{C}$ and then subjected to two cycles of freezing and thawing. The lysates were lysed with an equal volume of RIPA buffer (pH 7.5) and incubated for $1 \mathrm{~h}$ at $37^{\circ} \mathrm{C}$. The solubilized samples were applied into ELISA plates coated with guinea pig anti-SP antibodies. Goat primary antibodies against rotavirus SP and HRP-conjugated rabbit anti-goat secondary antibodies were used and the reaction was developed with OPD substrate as indicated above. TLPs treated with BSA or left un-treated and cell lysates from non-infected cells were used as a controls.

Statistical analysis. Data analysis was performed with the GraphPad Prism v5.0 software program. A two-way ANOVA was used to determine the significance of the differences between treatments. P-value $<0.05$ was considered as statistically significant.

\section{Results}

Expression of HSPs, PDI and integrin $\beta 3$ on cell surface

To examine the presence of Hsp90, Hsp70, Hsc70, Hsp60, Hsp40, PDI and integrin $\beta 3$ on the Reh cell surface, we performed a flow cytometry analysis after treatment of cells with specific antibodies directed to these cellular proteins. The analysis showed a differential expression of these proteins in the cell population examined. Depending on the protein examined, the expression on cell surface ranged from 3.2 to $92.3 \%$ with Hsp90-positive cells showing the highest percentage of expression in the cell population (Fig. 1a). Quantification of expression for each protein is shown as MFI (Fig. 1b).

\section{Interaction of HSPs with PDI and integrin $\beta 3$ on cell surface}

To determine whether the Hsp90, Hsp70, Hsc70, Hsp60, Hsp40, PDI and integrin $\beta 3$ are able to interact on the cell surface, RIPA solubilized cell membrane enriched fractions were examined by ELISA using capture antibodies to PDI, Hsc70 or integrin $\beta 3$. Detection of the proteins binding to the captured proteins showed that a positive binding was observed for Hsp90 when integrin $\beta 3$ capture antibody was used. Similar delta OD values were obtained for Hsp70, Hsp60, Hsp40, Hsc70 and PDI (Fig. 1c). In the case of Hsc70 capture antibody, significant delta OD values were obtained for Hsp70 and Hsp40 binding (Fig. 1d). When PDI capture antibody was used, significant delta OD values were observed for both $\mathrm{Hsp} 40$ and Hsp70 (Fig. 1e). These results suggest that integrin $\beta 3$ is forming a complex in which are present all the examined proteins, while PDI appears to form a complex with Hsp70 and Hsc70 only. However, the participation of other proteins in this complex cannot be excluded. 
(a)

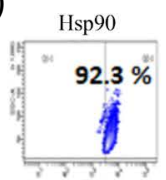

$\mathrm{Hsc} 70$

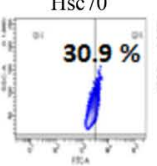

(c)

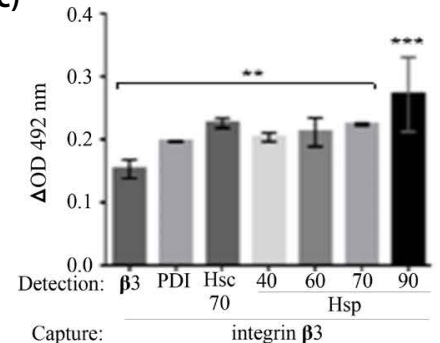

(d)

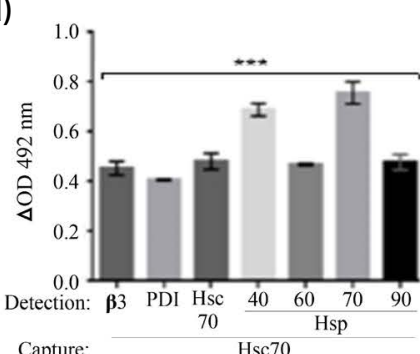

(b)

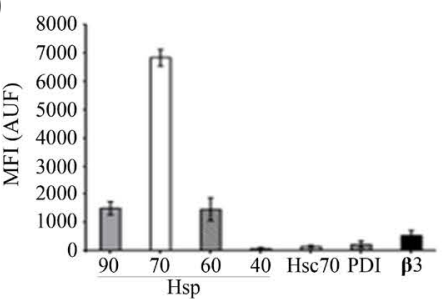

(e)

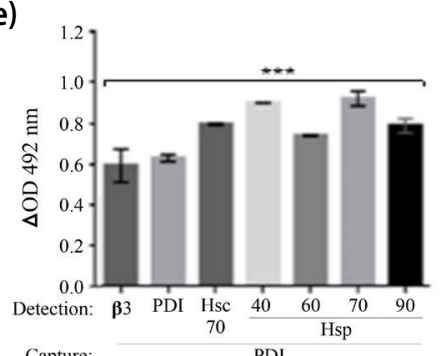

(f)

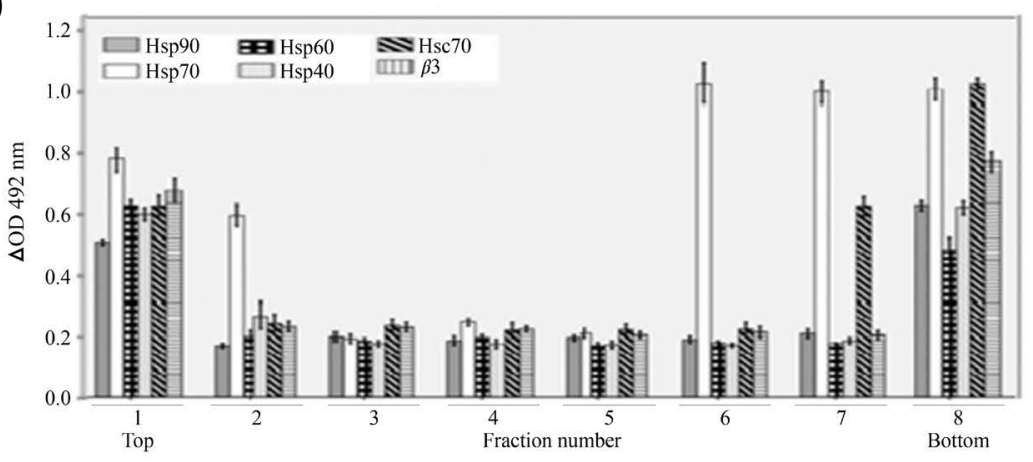

(g)

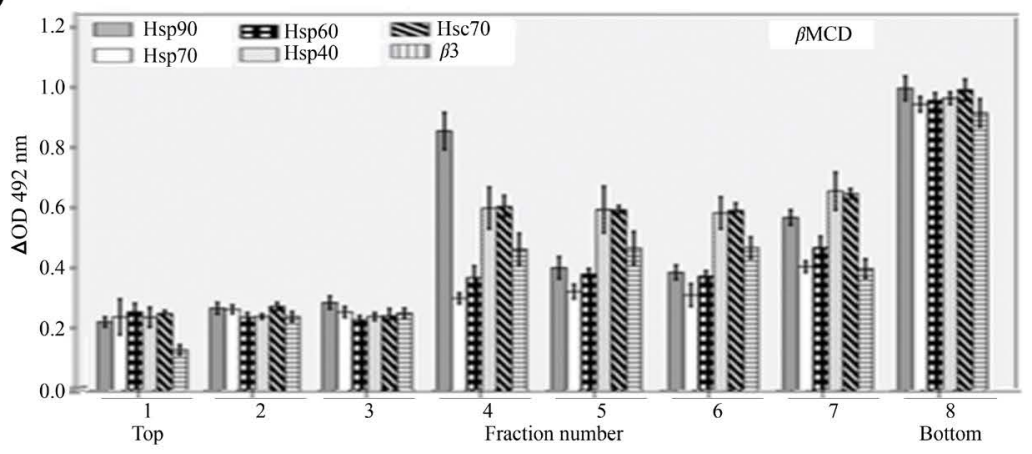

Fig. 1

Localization of Hsp90, Hsp70, Hsp60, Hsp40, Hsc70, PDI and integrin $\beta 3$ in the cell membrane

Immunofluorescence analysis by flow cytometry of cells stained with Alexa Fluor 488-conjugated IgG for the indicated cellular proteins (a). Fluorescence data were expressed as MFI and isotype antibodies were used as a negative control (b). ELISA analysis of RIPA buffer-solubilized cell membrane-enriched fractions captured by antibodies to integrin $\beta 3$. Detection was performed by primary antibodies to $\mathrm{Hsp} 90, \mathrm{Hsp} 70$, Hs60, Hsp40, Hsc70, $\beta 3$, or PDI and secondary HRP-conjugated antibody. Plates were read at $492 \mathrm{~nm}$ and the results expressed as delta OD values (c). Reactions were as indicated in “(c)" except that ELISA plates were coated with capture antibodies to Hsc70 (d). Reactions were as indicated in "(c)" except that ELISA plates were coated with capture antibodies to PDI (e). Sucrose gradient centrifugation of lysates from cells treated with methyl- $\beta$-cyclodextrin for isolation of rafts. Gradient fractions were analyzed by ELISA using capture antibodies to integrin $\beta 3$. Detection was performed using antibodies to Hsp90, Hsp70, Hsp60, Hsp40, Hsc70 or integrin $\beta 3$ and HRP-conjugated IgG as secondary antibody. The reaction was visualized using OPD and reading at $492 \mathrm{~nm}$ (f). Procedures were as described in "(f)" except that cells were non-treated with methyl- $\beta$-cyclodextrin. Data are shown as mean \pm SD of three independent experiments performed in duplicate (g). Statistical significance is indicated by $p$-values $\left({ }^{* * *} \mathrm{p} £ 0.01,{ }^{* *} \mathrm{p} £ 0.05\right.$, and $\left.{ }^{*} \mathrm{p} £ 0.1\right)$. 


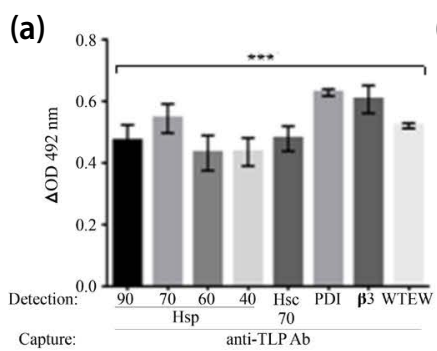

(b)

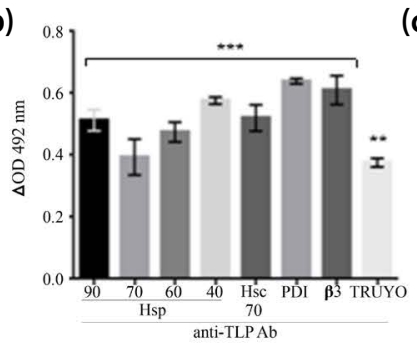

(f)

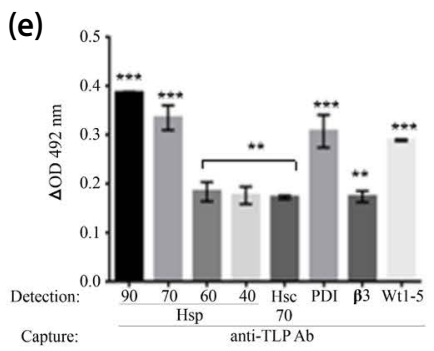

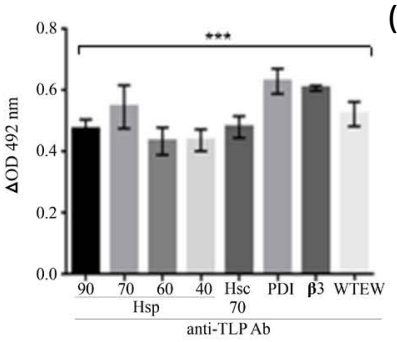

(c)

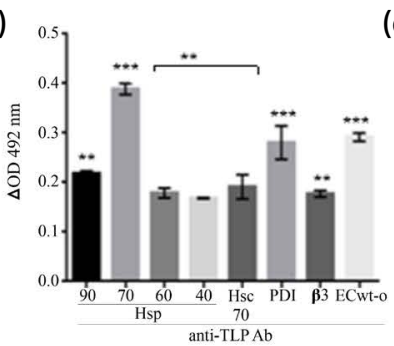

(d)

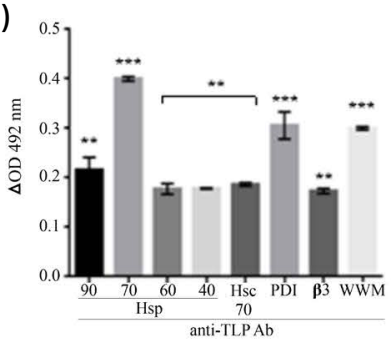

(g)

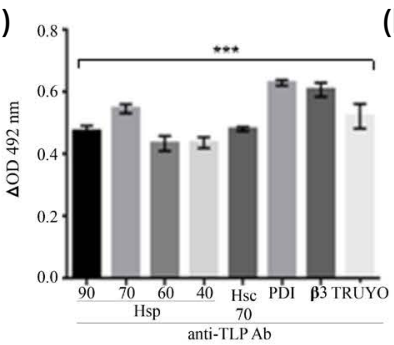

(h)

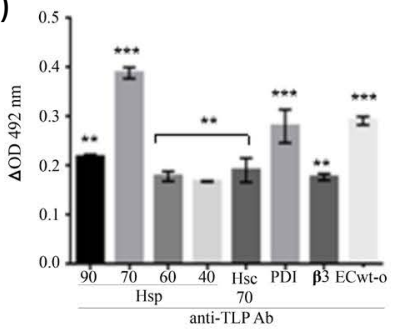

(i)

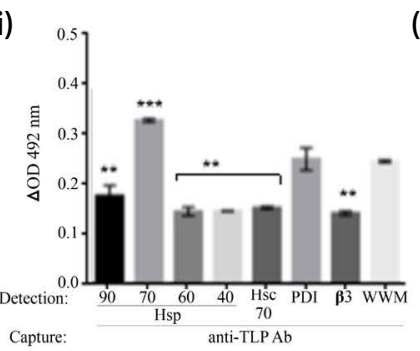

(j)

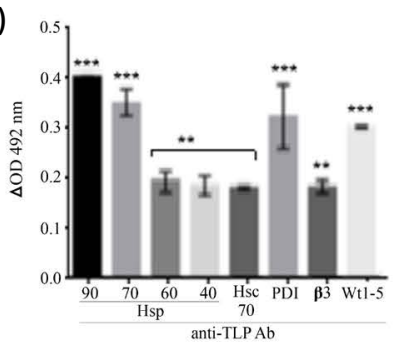

Fig. 2

Binding of rotavirus isolates to Hsp90, Hsp70, Hsp60, Hsp40, Hsc70, PDI and integrin $\beta 3$

Incubation of Reh cells (a-e) or their cell membrane enriched fractions $(\mathbf{f}-\mathbf{j})$ with the indicated rotavirus isolates. RIPA-solubilized preparations were applied into ELISA plates coated with capture antibodies to rotavirus structural proteins. Detection was carried out with primary antibodies to HSPs, PDI, Hsc70, integrin $\beta 3$ or rotavirus particles and HRP-conjugated IgG as secondary antibody. Data are shown as mean $\pm S D$ of three independent experiments performed in duplicate. Statistical significance is indicated by $\mathrm{p}$-values $\left({ }^{* * * *} \mathrm{p} £ 0.01\right.$, ${ }^{* *} \mathrm{p} £ 0.05$, and $\left.{ }^{*} \mathrm{p} £ 0.1\right)$.

\section{Presence of HSPs in lipid rafts}

To examine whether the HSPs expressed on the cell surface are associated in lipid microdomains - rafts, cells treated or un-treated with methyl- $\beta$-cyclodextrin were lysed and analyzed in a sucrose gradient. The ELISA analysis of the Triton X-100-solubilized sucrose gradient fractions from un-treated cells showed that the integrin $\beta 3$ antibodycaptured proteins reacted with antibodies to Hsp90, Hsp70, Hsp60, Hsp40, and Hsc70 in samples taken from the fraction 1 (Fig. 1f), while methyl- $\beta$-cyclodextrin-treated cells showed that the protein bound by the integrin $\beta 3$ capture antibody reacted with antibodies to Hsp90, Hsp70, Hsp60, Hsp40, and Hsc70 in samples taken from the fractions 4 to 8 (Fig.1g). These results suggest that integrin $\beta 3$ can interact, whether directly or indirectly, with Hsp90, Hsp70, Hsp60, Hsp40, Hsc70, and PDI to form complexes in lipid rafts.
Binding of rotavirus isolates to HSPs, PDI, and integrin $\beta 3$

Since Hsp90, Hsp70, Hsp60, and Hsp40 were found to be forming complexes with Hsc70, PDI, and integrin $\beta 3$ as described above, we wanted to investigate whether the viral particles of rotavirus isolates were able to bind to these complexes. To gain insight into the occurrence of these probable interactions, cells or cell membraneenriched fractions were incubated with rotavirus isolates WTEW, TRUYO, WWM, Wt1-5 or ECwt-o and then the RIPA cell lysates or RIPA solubilized cell membrane-enriched fractions were analyzed by ELISA using anti-rotavirus capture antibodies. In the case of both cells (Fig. 2a-e) and cell membrane-enriched fractions (Fig. 2f-j), the detection with antibodies to Hsp90, Hsp70, Hsp60, Hsp40, PDI, integrin $\beta 3$, and Hsc70 showed positive and significant 
(a)

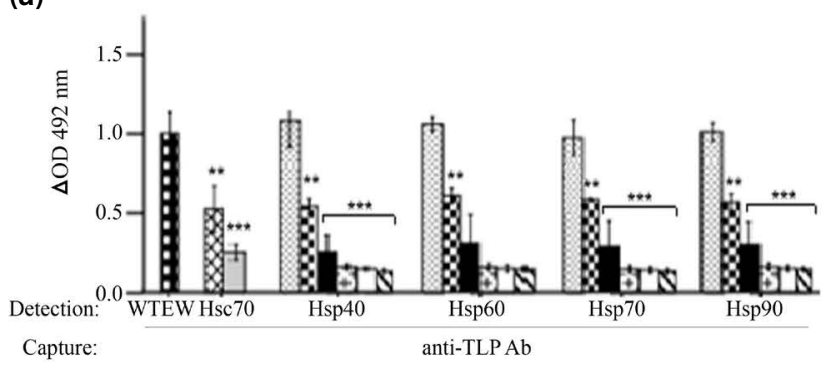

(c)

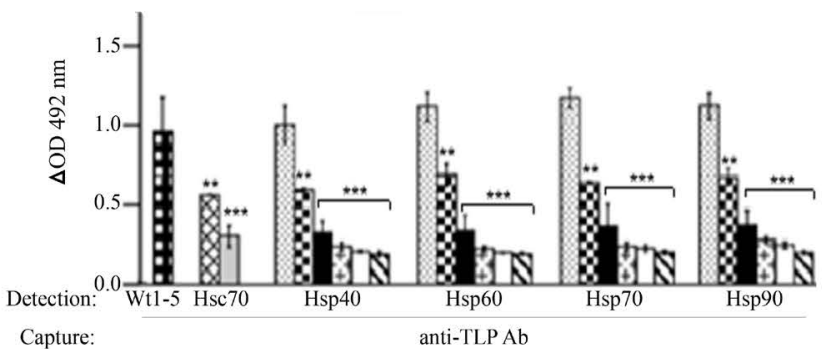

(b)

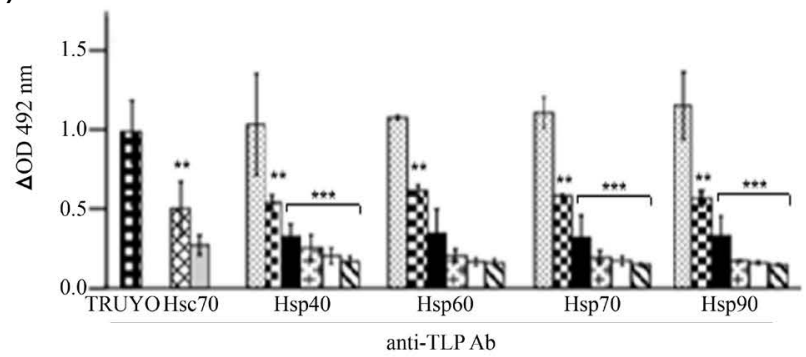

(d)

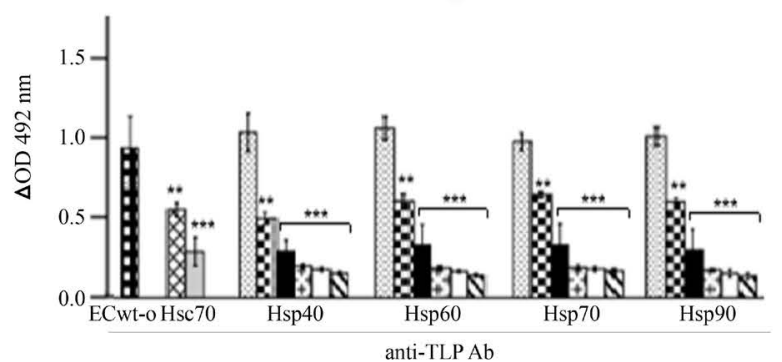

(e)

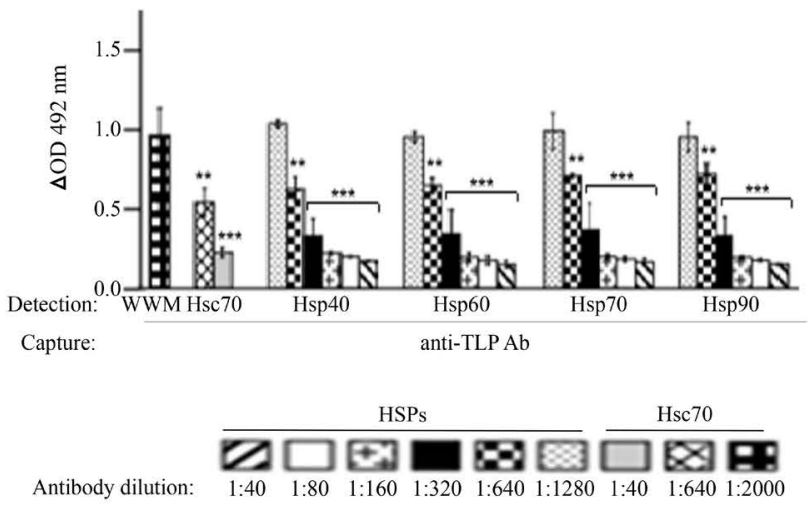

Fig. 3

Blocking of rotavirus binding to the cell surface by antibodies against Hsp90, Hsp70, Hsp60, Hsp40, and Hsc70

Pretreatment of Reh cells with F(ab')2 antibody fragments against to Hsp90, Hsp70, Hsc70, Hsp60 or Hsp40 before incubation with the rotavirus isolates indicated in panels. Cells were solubilized with RIPA buffer before addition to ELISA wells coated with capture antibodies to rotavirus particles. Detection was carried out with antibodies to rotavirus particles and the reaction was measured using HRP-conjugated IgG and OPD substrate (a-e). Data are shown as mean \pm SD of three independent experiments performed in duplicate. Statistical significance is indicated by $\mathrm{p}$-values $\left({ }^{* * *} \mathrm{p} £ 0.01,{ }^{* *} \mathrm{p} £ 0.05\right.$, and $\left.{ }^{*} \mathrm{p} £ 0.1\right)$.

reactions for these cellular proteins in case of all the rotavirus isolates tested (Fig. 2a-j). These results suggest that rotavirus particles are forming direct or indirect complexes with the cellular proteins assayed.

Inhibition of rotavirus binding by $F\left(a b^{\prime}\right) 2$ fragments against HSPs

To confirm the binding of rotavirus particles to cell surface Hsp90, Hsp70, Hsp60, and Hsp40, cells pre- treated with increasing concentrations of $F\left(a b^{\prime}\right) 2$ fragments to these cellular proteins were inoculated with the indicated rotavirus isolates. The ELISA analysis using anti-rotavirus capture antibodies showed a decreasing amount of rotavirus particles bound to cells that correlated with the increasing amounts of $F\left(a b^{\prime}\right) 2$ fragments to HSPs (Fig. 3a-e). These data suggest that cell Hsp90, Hsp70, Hsp60, and Hsp40 are being used by all the rotavirus isolates tested. 
(a)

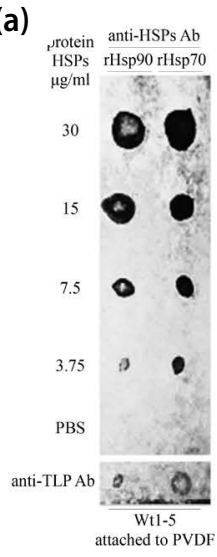

(b)

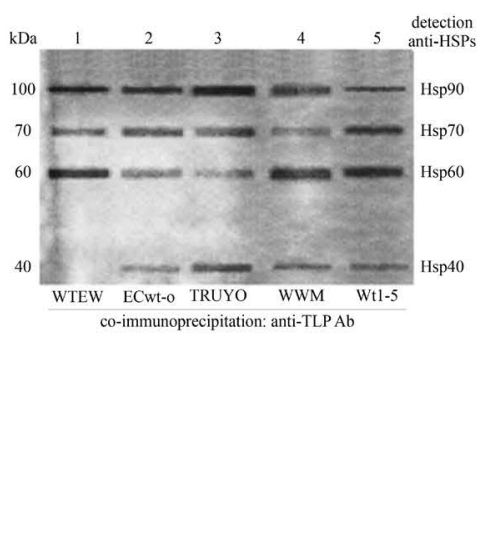

(c)

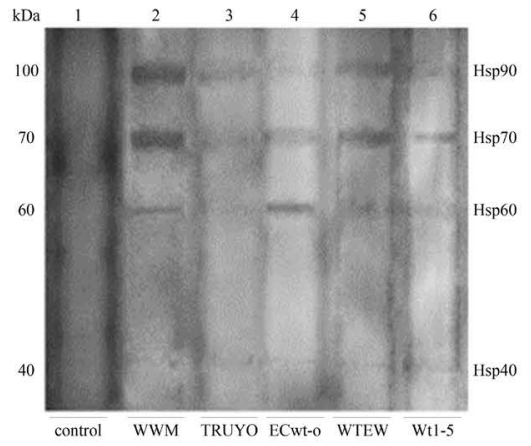

(d)

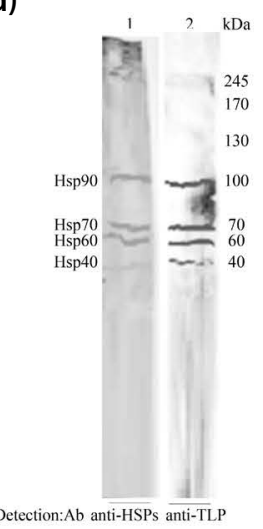

(e)

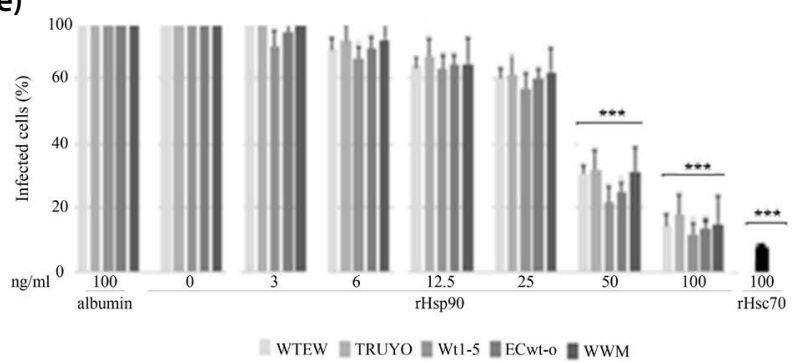

(f)

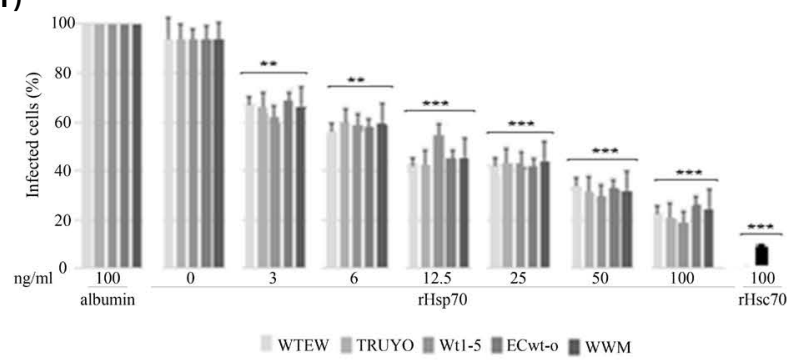

Fig. 4

Binging of rotavirus particles to $\mathrm{Hsp90}, \mathrm{Hsp70}, \mathrm{Hsp} 60$ and $\mathrm{Hsp} 40$, and inhibition of rotavirus infection by competition for binding to these HSPs

Dot blot analysis of a suspension from WTEW isolate bound to PVDF membrane and incubated with rHsp90 or rHsp70. HSPs were detected with their respective antibodies and the reaction detected with HRP-conjugated antibody and AEC substrate (a). Incubation of cell membrane-enriched fractions with the indicated rotavirus isolates. RIPA-solubilized cell membrane fractions were immunoprecipitated with agarose bead-coupled antibodies against rotavirus particles. The immunoprecipitated proteins were analyzed by SDS-PAGE/Western blotting using antibodies against the indicated HSPs and luminol-based detection (b). Biotinylation of cell surface proteins with NHSSS-Biotin (succinimidyl-2-(biotinamido)-ethyl-1,3'-dithiopropionate before incubation with the indicated trypsin-activated rotavirus. RIPA-lysed cells were immunoprecipitated with Protein A-agarose beads coated with antibodies to rotavirus structural proteins (SP). The precipitated protein was analyzed by SDS-PAGE/Western blotting and the biotinylated proteins detected with HRP-streptavidin conjugate. The positions of the HSPs are indicated (c). VOBPA assay of RIPA-lysed cells followed by non-denaturing and non-reducing PAGE/Western blotting analysis. The membrane was incubated with Wt1-5 and treated with a mix of antibodies to the HSPs (lane 1) indicated above or antibodies to rotavirus TLPs (lane 2) (d). Treatment of rotavirus isolates with the indicated concentrations of rHsp90 before incubation with cells. BSA or Hsc70-treated rotavirus isolates were used as a control. RIPA-lysed cells were analyzed by ELISA using capture antibodies to rotavirus particles. Detection was performed with antibodies to rotavirus particles. The reaction was revealed with HRP-conjugated IgG and OPD (e). Reactions were as indicated in “(e)" except that rHsp70 was used instead of rHsp90 (f). Data are shown as mean \pm SD of three independent experiments performed in duplicate. Statistical significance is indicated by $p$-values $\left({ }^{* * *} \mathrm{p} £ 0.01,{ }^{* *} \mathrm{p} £ 0.05\right.$, and $\left.{ }^{*} \mathrm{p} £ 0.1\right)$.

\section{Binding of rotavirus particles to rHSPs in dot blot assay}

To further investigate the binding of Hsp90 and Hsp70, with rotavirus particles, TLPs from rotavirus isolate Wt15 were bound to PVDF membrane in a dot blot assay and then incubated with rHsp90 or rHsp70. The detection with antibodies to Hsp90 and Hsp70-derived synthetic peptides showed positive reactions for these cellular proteins (Fig. 4a). In a reciprocal experiment, in which serial increasing dilutions of rHsp90 or rHsp70 were bound to the membrane, the reaction area for TLP anti- gens was continuously decreasing as the concentration of the recombinant proteins decreased (data not shown). These data suggest that Wt1-5 TLPs and the HSPs tested are directly interacting.

\section{Co-immunoprecipitation of HSPs with rotavirus particles}

We next assessed the occurrence of the interaction of Hsp90, Hsp70, Hsp60, and Hsp40 with rotavirus isolates WTEW, TRUYO, WWM, Wt1-5, and ECwt-o by incubating these trypsin-activated isolates with cell membrane- 

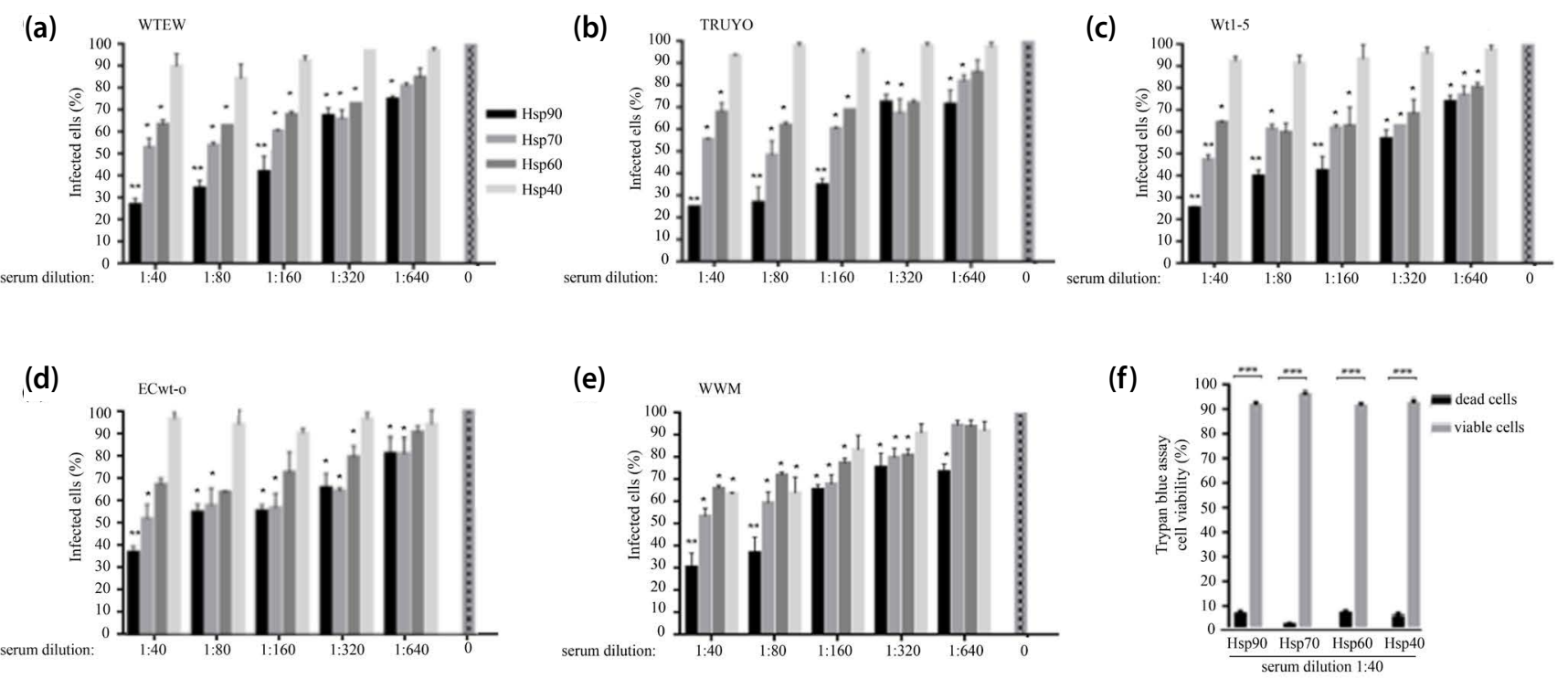

Fig. 5

Inhibition of rotavirus infection by antibodies to Hsp90, Hsp70, Hsp60 or Hsp40

Treatment of cells with a serial dilution of antibodies to the indicated HSPs before incubation with the rotavirus isolates indicated in panels. Structural rotavirus antigens were detected by immunocytochemistry assay. Virus-inoculated cells without antibody pre-treatment were used as a control. Data are expressed as the percentage of infected cells (a-e). Cell viability of cells treated with an antibody against to Hsp90, Hsp70, Hsp60 or Hsp40. The percentages of viable cells at the indicated dilution are shown (f). Data are shown as mean \pm SD of three independent experiments performed in duplicate. Statistical significance is indicated by $p$-values $\left({ }^{* * *} \mathrm{p} £ 0.01,{ }^{* *} \mathrm{p} £ 0.05\right.$, and $\left.{ }^{*} \mathrm{p} £ 0.1\right)$.

enriched fractions. The immunoprecipitation assay with agarose beads coated with antibodies to rotavirus structural proteins, followed by an SDS-PAGE/Western blot analysis, showed protein bands reacting with antibodies to Hsp90, Hsp70, Hsp60, and Hsp40. The molecular masses of these protein bands were compatible with the expected molecular sizes for these cellular proteins (Fig. 4b). These results further confirm that rotavirus particles are able to interact with the HSPs tested.

In an additional assay, the cell surface proteins were biotinylated before incubation with the rotavirus isolates. The subsequent SDS-PAGE/Western blot analysis of the immunoprecipitated proteins with antibodies to rotavirus particles showed that the protein bands had molecular masses corresponding to the expected sizes of Hsp90, Hsp70, Hsp60, and Hsp40 (Fig. 4c).

\section{Binding of rotavirus particles to HSPs detected by VOPBA}

To further confirm the interaction of the rotavirus particles with Hsp90, Hsp70, Hsp60, and Hsp40, a VOPBA analysis was conducted by subjecting cell lysates to SDSPAGE in non-reducing conditions. After incubation of the Wt1-5 isolate with the PVDF membrane containing the transferred cellular proteins, protein bands with molecular mass values close to those expected for Hsp90, Hsp70, Hsp60, and Hsp40 were observed following the visualization with antibodies to rotavirus structural proteins (Fig. 4d). A parallel membrane without treatment with rotavirus particles showed similar pattern (Fig. 4d). These results further confirm that rotavirus particles are able to bind the HSPs assayed.

Inhibition of infection by pre-treatment of rotavirus particles with $\mathrm{rHsp} 90$ and $\mathrm{rHsp70}$

To determine whether the binding of HSPs to rotavirus particles affects viral infection, the rotavirus isolates TRUYO, WWM, WTEW, Wt1-5, and ECwt-o were pre-treated with decreasing concentrations of $\mathrm{rHsp} 90$ or $\mathrm{rHsp70}$ before inoculation into Reh cells. After incubation for $12 \mathrm{~h}$ at $37^{\circ} \mathrm{C}$, the ELISA analysis for the total rotavirus structural antigens accumulated in cell lysates showed that pre-treatment with recombinant HSP decreased the percentage of the accumulated viral antigen in cells that was dose-dependent for all the rotavirus isolates tested (Fig. 4e, f). The corresponding rotavirus isolate without HSP pretreatment was used as the $100 \%$ infection control. In the case of cells infected with the corresponding 
(a)
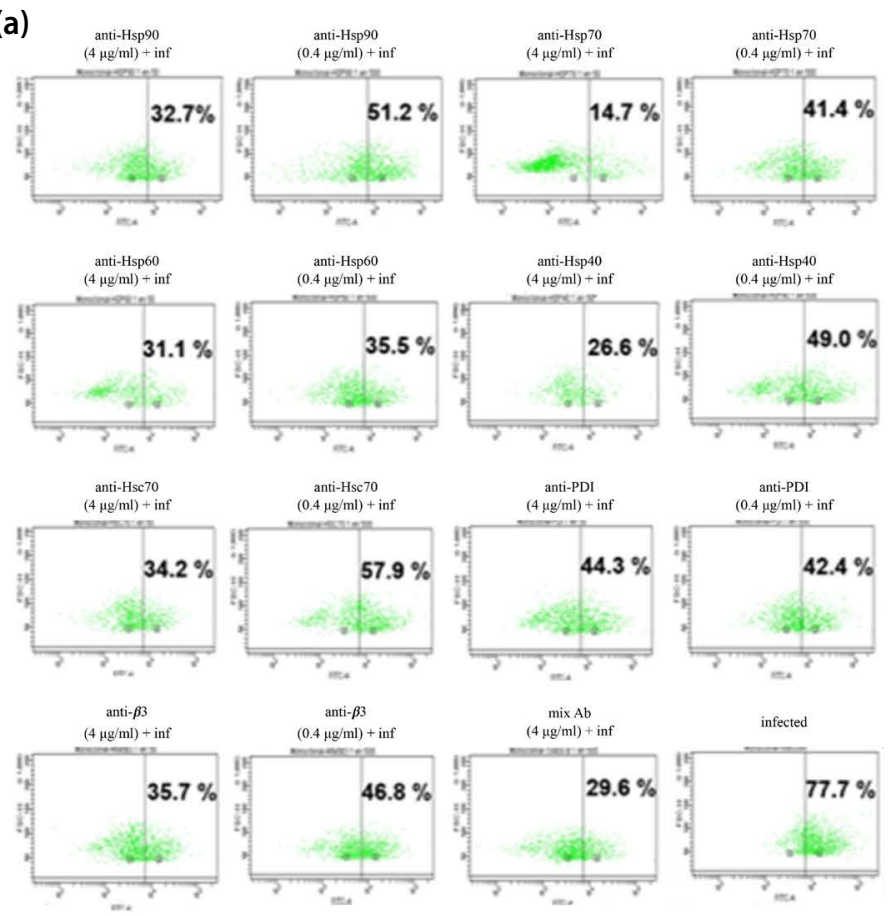

Fig. 6

Inhibition of Wt1-5 infection by commercial antibodies to Hsp90, Hsp70, Hsp60, Hsp40, Hsc70, PDI, and $\beta 3$

Treatment of cells in logarithmic phase of growth with the indicated concentrations of antibodies to Hsp90, Hsp70, Hsp60, Hsp40, Hsc70, PDI, or $\beta 3$ before infection with trypsin-activated Wt1-5. The cells were examined by flow cytometry for the expression of rotavirus structural antigens (a). Isotype antibodies against potato virus $\mathrm{Y}(\mathrm{PVY})$ were used as a negative control (b). Cells treated and infected as indicated in "(a)" were analyzed for the presence of rotavirus antigens. The percentages of cells being positive to rotavirus antigens are shown. The fluorescence intensity of cells analyzed in "(a)" by flow cytometry is shown as MFI (c). Cell viability examined with resazurin of cells previously treated with antibodies to Hsp90, 70, 60, 40, Hsc70, PDI, and 33 . Non-infected cells and cells infected with Wt1-5 without antibody pre-treatment were used as a control. Percentages of cell viability are shown (d). Data are shown as mean \pm SD of three independent experiments performed in duplicate. Statistical significance is indicated by $\mathrm{p}$-values $\left({ }^{* * *} \mathrm{p} £ 0.01,{ }^{* *} \mathrm{p} £ 0.05\right.$, and $\left.{ }^{*} \mathrm{p} £ 0.1\right)$.
Hsp90-pretreated rotavirus, the highest decrease in the percentage of infected cells ranged between 78 and $84.7 \%$, while this range was slightly lower for $\mathrm{rHsp} 70$ (64.9-75.1\%) (Fig. 4e, f). The positive control represented by the Hsc70pretreated rotavirus using the highest comparable Hsc70 concentration caused inhibition of WTEW or Wt1-5 infection by $92.2 \%$ and $96.2 \%$, respectively (Fig. 4 e). The cell viability in the presence of the highest concentration used for pretreatment of viral particles was 97 and $96 \%$ for Hsp90 and Hsp70, respectively (data not shown). The results obtained after pretreatment of rotaviruses with the recombinant HSPs suggest that the recombinant proteins used in the pretreatment, competed with their cell surface counterparts. (b)

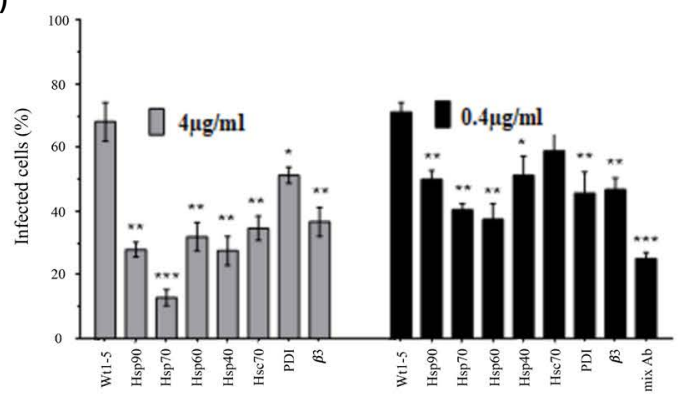

(c)

(d)
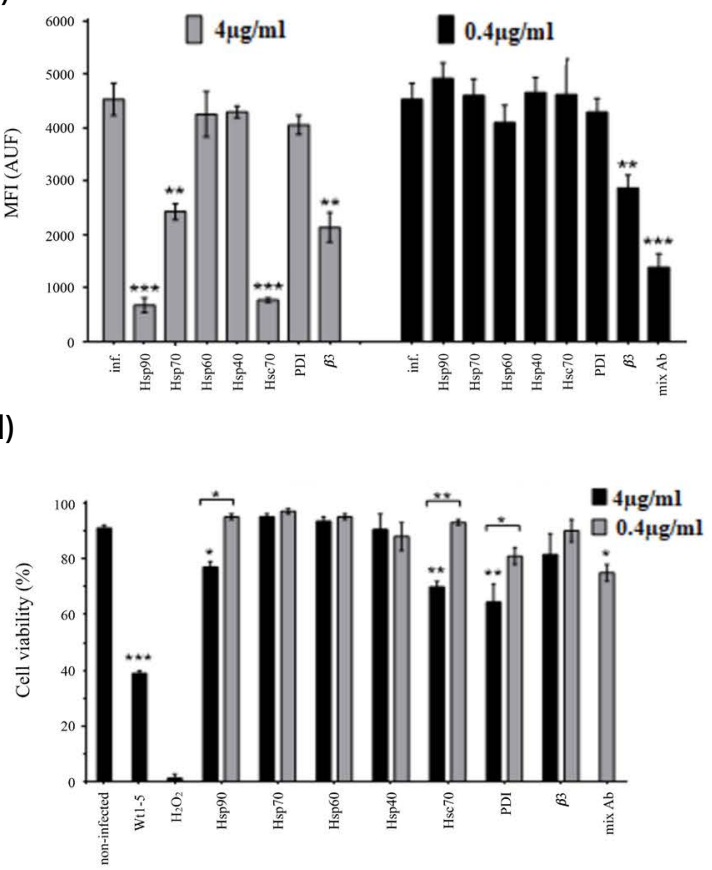
HSPs

Inhibition of viral infection by antibody blocking of

To further investigate the particular function of Hsp90, Hsp70, Hsp60, and Hsp40 in the virus infection, rabbit polyclonal antibodies directed to synthetic peptides derived from these proteins were used to pretreat cells before infection with the indicated rotavirus isolates. Pretreatment of cells with HSP antibodies differentially inhibited rotavirus infection depending on the rotavirus isolate and the particular HSP tested. The maximum inhibition values produced by the antibody pretreatment of cells are shown as the proportion of infected cells compared to the cells that did not have antibody pretreatment 
(Fig. 5a). At the lowest antibody dilution used, the highest infectivity inhibition was observed with the Hsp90 antibody cell pretreatment for WTEW (72\%), Wt1-5 (75\%), ECwt-o (62\%), and WMW (70\%), while TRUYO showed its highest inhibition (75\%) after cell pretreatment with antibodies to several Hsp70 domains (Fig. 5a-e). Reduction of infectivity by cell pretreatment with antibodies to Hsp70, Hsp60, and Hsp40 was not higher than $52 \%$ for all the rotavirus isolates assayed (Fig. $5 \mathrm{a}-\mathrm{e}$ ) at the lowest antibody dilution used. To evaluate the effect of the antibodies to HSPs on cell viability, we tested the antibodies at increasing concentrations. By the trypan blue assay, it was found that the percentages of cell viability for Reh cells were $94 \%, 98 \%, 93 \%$, and $96 \%$ after treatment with antibodies to Hsp90, Hsp70, Hsp60, and Hsp40, respectively, at the highest concentrations used (Fig. 5f). Overall, these results suggest that the rotavirus particles use the tested cell surface HSPs as receptors to infect Reh cells.

In order to further analyze the implication of HSPs and other cell surface proteins during the rotavirus infection of Reh cells, cell surface Hsp90, Hsp70, Hsp60, Hsp40, Hsc70, PDI and integrin $\beta 3$ were blocked with commercial goat antibodies ( 4 and $0.4 \mu \mathrm{g} / \mathrm{ml}$ ) or with a mixture of these antibodies $(0.4 \mu \mathrm{g} / \mathrm{ml}$ each). After infection with the rotavirus isolate Wt1-5, the dot plot flow cytometry analysis of the cells stained for rotavirus antigens (Fig. $6 a)$ showed that the percentage of cells positive for viral antigens was differentially decreased depending on the blocked cell surface protein. The antibodies to Hsp90 reduced the proportion of infected cells by $67.3 \%$ (at $4 \mu \mathrm{g} / \mathrm{ml}$ ) and $47.8 \%$ (at (at $0.4 \mu \mathrm{g} / \mathrm{ml}$ ) while Hsp70 antibody pretreatment of cells reduced the infectivity by $85.3 \%$ and $58.6 \%$, respectively (Fig. 6b). Similar reductions in viral infectivity were caused by pretreatment of cells with antibodies to the remaining HSPs tested: Hsp60 (68.4 and 64.5\%), Hsp40 (73.4 and 51\%), and Hsc70 (65.8 and 42.1\%) (Fig. 6b). Slightly lower reduction in viral infectivity occurred when cells were pretreated with antibodies to PDI (55.7 and 42.4\%) or integrin $\beta 3$ (64.3 and 53.2\%) (Fig. 6b). Interestingly, the effect of antibody treatment on viral infectivity was not additive as the pretreatment of cells with a mixture of all antibodies $(0.4 \mu \mathrm{g} / \mathrm{ml}$ each) produced a viral infectivity reduction of only $70 \%$ (Fig. $6 \mathrm{~b}$ ).

When the reduction of infectivity determined by reduction of the viral antigen accumulated in cells was shown as MFI on the dot plots, it was found that highest inhibitory effect on viral antigen accumulation was caused by Hsp90 and Hsc70 antibody pretreatment of cells, followed by the Hsp70 and integrin $\beta 3$ antibody pretreatment (Fig. 6c). A significant reduction of the median fluorescence intensity (MFI) for the cells pretreated with the antibody mixture was also observed (Fig. 6c). MFI was not reduced in the case of the remaining antibodies used in the pretreatment of cells when compared to the MFI corresponding to the cells without antibody pretreatment (Fig.6c).Cytotoxic effects produced by the antibodies were discarded as mitochondrial metabolic activity and cell viability were similar for antibody-pretreated or untreated cells (Fig. 6d). These results indicate that the cell surface proteins examined are participating at least in the entry process of the Wt1-5 strain particles.

\section{tion \\ Effects of Hsp90 and Hsp70 inhibitors on viral infec-}

To determine whether the HSPs studied are only virusbinding proteins or whether their ATPase activity is also required for rotavirus infection, the cells were preincubated with the Hsp90 inhibitors 17AAG, NVP-AUY922, and radicicol or the Hsp70 inhibitors VER-155 008, and quercetin at different concentrations. After $12 \mathrm{hpi}$, the percentage of infected cells was decreased by the inhibitor pretreatment of cells. The inhibition was dependent on both the inhibitor and the rotavirus isolate (Fig. 7a-f). At the highest inhibitor concentrations, Hsp90 inhibitors reduced the proportion of infected cells by $37 \%$ to $87 \%$, while Hsp70 inhibitors by $62 \%$ to $87 \%$ depending on the inhibitor and the rotavirus isolate (Fig. 7a-f). The less sensitive rotavirus isolate was TRUYO (37\%) after pretreatment with the Hsp90 inhibitor NVP-AUY (Fig. 7b) while the most sensitive rotavirus isolate was Wt1-5 when the cells were pretreated with radicicol (87\%) (Fig. 7d). In the case of cell pretreatment with quercetin $(300 \mu \mathrm{M})$ at $43^{\circ} \mathrm{C}$ for $30 \mathrm{~min}$, the inhibition reached $100 \%$ and $82 \%$ for isolates WTEW and Wt1-5, respectively (Fig. 7f). The percentage of inhibition using the same inhibitor was 64 and $70 \%$ at $37^{\circ} \mathrm{C}$ for isolates WTEW and Wt1-5, respectively (Fig. 7f). Cell viability after inhibitor application, as determined with the trypan blue exclusion test, ranged from 90 to 99.5\% (Fig. 7g). These percentages suggest that the used inhibitors did not significantly affect the cell viability. The effect of the HSP inhibitors on the virus infection suggests that the inhibition of one HSP is not enough to completely inhibit the virus infection. It sounds plausible that rotaviruses can use alternative cell surface receptors for binding and entry into the host cell.

\section{Discussion}

Entry of rotavirus particles into the target cell is a multistep process depending on cell surface molecules, including Hsc70 (Guerrero et al., 2002). Some viruses have been reported to use HSPs for binding to the host cells (Xu et al., 2019; Reyes-del Valle et al., 2005; Lin et al., 2007). In our experimental approach, Hsp90, Hsp70, Hsp60, Hsp40, 
(a)

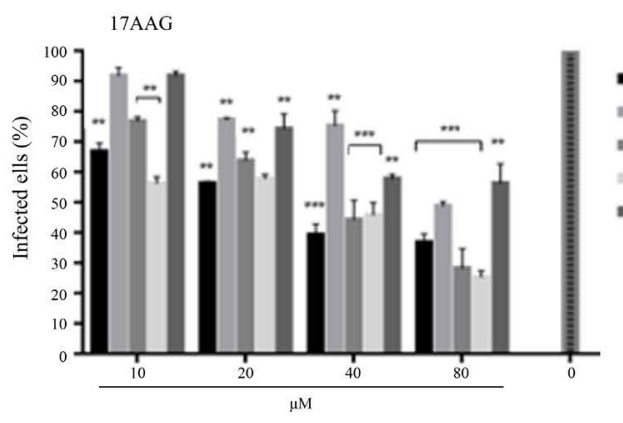

(c)

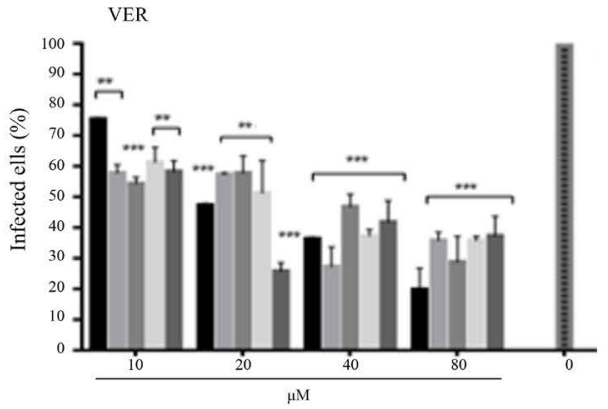

(e)

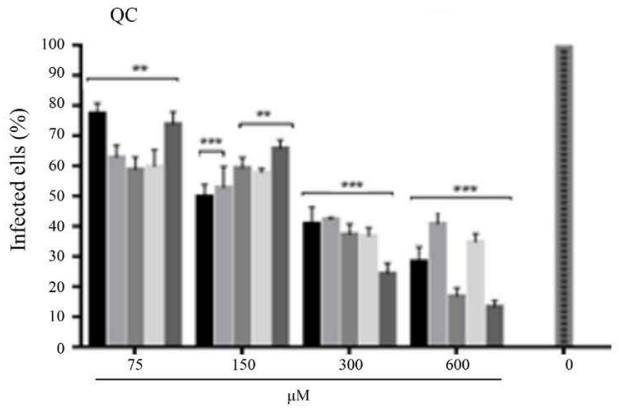

(b)

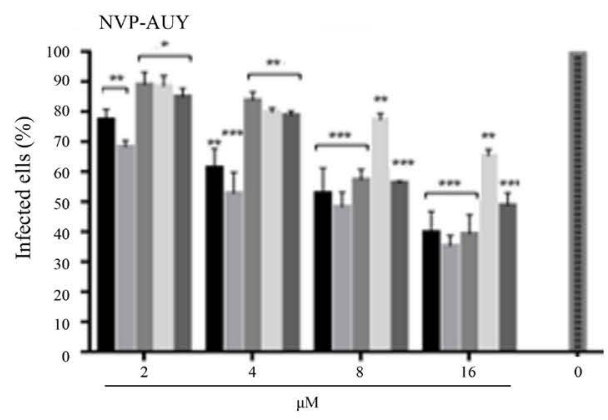

(d)

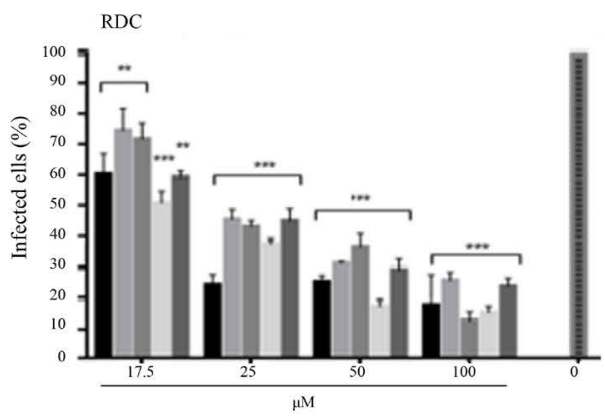

(f)

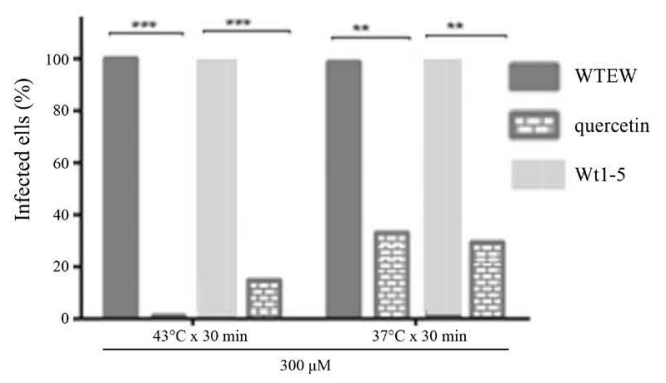

(g)

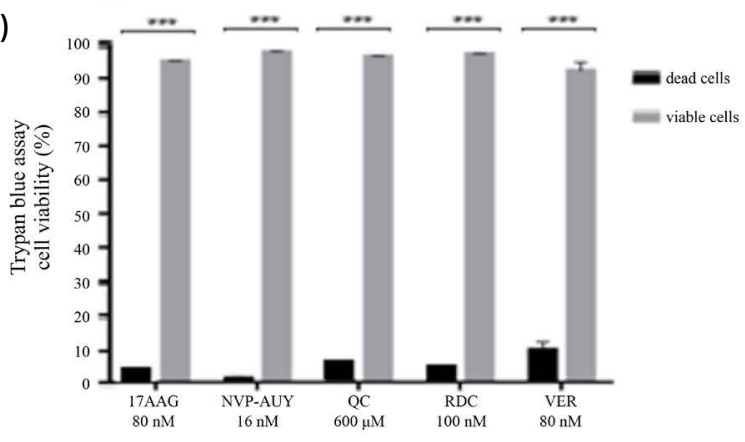

Fig. 7

Effect of inhibition of Hsp90 and Hsp70 on rotavirus infection

Treatment of cells with different concentrations of Hsp90 inhibitors (17AAG, NVP-AUY or radicicol) or Hsp70 inhibitors (quercetin (QC) or VER155008) before inoculation with the rotavirus isolates indicated in panels. Viral structural antigens were detected by immunochemistry assay and infection was expressed as the percentage of infected cells (a-e). Incubation of cells with QC at 43 or $37^{\circ} \mathrm{C}$ before infection with WTEW or Wt1-5. Percentages of infected cells determined by immunocytochemistry assay are shown (f). Cell viability of the cells treated with $600 \mathrm{mM}$ of the indicated HSP inhibitors (g). Data are shown as mean \pm SD of three independent experiments performed in duplicate. Statistical significance is indicated by $\mathrm{p}$-values $\left({ }^{* * *} \mathrm{p} £ 0.01,{ }^{* *} \mathrm{p} £ 0.05\right.$, and $\left.{ }^{*} \mathrm{p} £ 0.1\right)$. 
Hsc70, PDI, and integrin $\beta 3$ were found exposed on the cell surface, although their presence was variable in the population of Reh cells. Moreover, the rotavirus isolates were susceptible to competitive inhibition by virion pretreatment with the soluble recombinant Hsp90 and Hsp70, suggesting that the binding of the recombinant proteins to the virions compete with the cell surface receptor binding. Blocking with antibodies directed to these cellular proteins present on the cell surface was able to substantially reduce rotavirus infection. However, antibody pretreatment of cells with a mixture containing all the antibodies against these cellular proteins was unable to cause $100 \%$ inhibition of viral infection. In consequence, it cannot be excluded that rotavirus binding and infection are mediated by still unknown receptors. Lack of additive effects by antibody blocking of cell receptors used by some rotavirus strains in MA104 cells has also been reported (Guerrero et al., 2002). Rotaviruses appear to use alternative entry pathways, some of them leading to unsuccessful entry and infection (Guerrero and Acosta, 2016). It is possible that other cell surface proteins are involved in facilitating rotavirus entry rather than functioning as a virus-binding protein. In addition, the implication of Hsp90 and Hsp70 in the rotavirus infection was further confirmed by the use of inhibitors of these HSPs since these inhibitors caused a significant inhibition of the infection by the different rotavirus isolates. These findings suggest that the ATPase activity of HSPs is needed during the entry process of rotavirus into the Reh cells. Since Hsp90 and Hsp70 are molecular chaperones, further research is needed to elucidate the eventual participation of the chaperone activity during rotavirus entry.

The interaction of Hsp90, Hsp70, Hsc70, Hsp60, Hsp40, PDI and integrin $\beta 3$ in lipid rafts, regardless of whether direct or indirect, strongly suggests that the physical proximity of these cellular proteins plays a role in the entry of rotavirus particles. Association of heat shock proteins with lipid rafts has already been demonstrated to be required for infection with some viruses (Reyesdel Valle et al., 2005; Zhu et al., 2012). To characterize the interaction between rotavirus and some HSPs, direct binding of rotavirus isolate Wt1-5 to rHsp90 and rHsp70 was demonstrated by a dot blot analysis. However, the detailed mechanism implicated in the binding and entry of the rotavirus isolates in the present work remains to be elucidated.

Despite the recent advances in the understanding of the mechanisms explaining the rotavirus infection, many events of rotavirus binding and penetration into the target cell remains to be elucidated. Rotaviruses appear to use alternative pathways for entry since the inhibition of the proposed cell surface receptors is unable to produce complete inhibition of the infection (Guerrero and Acosta,
2016). In addition, rotaviruses are internalized into the host cells using different types of endocytosis, and in a strain-dependent manner travel to different endosomal compartments before entering the cytosolic space (Arias et al., 2015). It has been proposed that rotaviruses use essentially three types of cellular molecules for entry into the host cells: 1) molecules for attachment such as SA and some integrins; 2) chaperone molecules, including Hsc70 and other HSP; and 3) redox molecules such as PDI, Erp57, and other thioredoxins (Guerrero and Acosta, 2016).

Although a wide array of cell surface molecules belonging to three non-related molecular families serve as rotavirus receptors, we show here that tumor cell-adapted rotaviruses require some cell surface-expressed HSPs as entry receptors. Our findings further extend the repertoire of molecules used by rotaviruses for entry into the host cell. Interestingly, these additional rotavirus receptor molecules identified here are abundantly expressed on the cell surface of many tumor cells, making them particularly sensitive to be targeted by rotaviruses. HSPs are commonly over-expressed in many solid tumors due to the well-known stress conditions characterizing the tumor cell challenging environment. In contrast, the HSPs identified in the present work are barely expressed in normal cells. Another striking feature of the HSPs functioning as rotavirus receptors is illustrated by their presence in lipid microdomains (rafts) forming a complex with other cell surface proteins already identified as rotavirus receptors such as Hsc70, PDI, and integrin $\beta 3$. The location of rotavirus receptors as a complex in rafts suggests temporospatial coordination of rotavirus entry events.

The results of the present study allows us to suggest that rotaviruses seem to share a general mechanism of entry but the specific molecules within the general three molecular categories proposed can differ partially and totally depending on the type of cell and the virus strain. The pathways used for rotavirus entry appear to depend on the relative abundance of the cell surface molecules involved and on their physical proximity, mainly in lipid microdomains (rafts). The penetration of rotavirus into the host cells is supposed to involve conformational changes in the rotavirus structural proteins produced by some of cell surface molecules. In this context, we postulate that the rotavirus isolates used in this study show some changes in their structural proteins which might have occurred during their selection through the repeated passages in tumor cells (Guerrero et al., 2016). These changes would explain the preferred tropism of these rotavirus isolates for tumor cells exhibiting high cell surface expression of Hsp90, Hsp70, Hsp60, and Hsp40, besides Hsc70.

The results of the present work further confirm that HSPs expressed on the cell surface of cells derived from 
human acute lymphocytic leukemia are used by tumor cell-adapted rotaviruses to cause infection. The results shown here encourage further research aim at evaluating the potential use of rotaviruses as an oncolytic agent for the treatment of some cancers.

Acknowledgments. This study was supported by a grant awarded to C. A. Guerrero by the Hermes-Quipu System (Code: 41543-201010029305).

\section{References}

Arias CF, Romero P, Alvarez V, López S (1996): Trypsin activation pathway of rotavirus infectivity. J. Virol.70, 5832-5839. https://doi.org/10.1128/JVI.70.9.5832-5839.1996

Arias CF, Silva-Ayala D, López S (2015): Rotavirus entry: a deep journey into the cell with several exits. J. Virol. 89, 890-893. https://doi.org/10.1128/JVI.01787-14

Banerji U, O'Donnell A, Scurr M, Pacey S, Stapleton S, Asad Y, Simmons L, Maloney A, Raynaud F, Campbell M, Walton M, Lakhani S, Kaye S, Workman P, and Judson I (2005): Phase I pharmacokinetic and pharmacodynamic study of 17-allylamino, 17-demethoxygeldanamycin in patients with advanced malignancies. J. Clin. Oncol. 23,4152-4161.https://doi.org/10.1200/JC0.2005.00.612

Besse B, Tsao LC, Chao DT, Fang Y, Soria JC, Almokadem S, Belani CP (2012): Phase Ib safety and pharmacokinetic study of volociximab, an anti- $\alpha 5 \beta 1$ integrin antibody, in combination with carboplatin and paclitaxel in advanced non-small-cell lung cancer. Ann. Oncol. 24, 90-96. https://doi.org/10.1093/annonc/mds281

Britten CD, Rowinsky EK, Baker SD, Weiss GR, Smith L, Stephenson J, Rothenberg M, Smetzer L, Cramer J, Collins W, Von Hoff DD, Eckhardt SG (2000): A phase I and pharmacokinetic study of the mitochondrial-specific rhodacyanine dye analog MKT 077. Clin. Cancer Res. 6, 42-49.

Calderon MN, Guerrero CA, Acosta O, Lopez S, Arias CF (2012): Inhibiting rotavirus infection by membrane-impermeant thiol/disulfide exchange blockers and antibodies against protein disulfide isomerase. Intervirology 55, 451-464. https://doi.org/10.1159/000335262

Chang CL, Hsu YT, Wu CC, Yang YC, Wang C, Wu TC, Hung CF (2012): Immune mechanism of the antitumor effects generated by bortezomib. J. Immunol. 189, 3209-3220. https://doi.org/10.4049/jimmunol.1103826

Chatterjee S, Burns T (2017): Targeting heat shock proteins in cancer: a promising therapeutic approach. Int. J. Mol. Sci. 18, 1978. https://doi.org/10.3390/ijms18091978

Chen SF, Nieh S, Jao SW, Liu CL, Wu CH, Chang YC, Yang CY, Lin YS (2012): Quercetin suppresses drug-resistant spheres via the p38 MAPK-Hsp27 apoptotic pathway in oral cancer cells. PLoS One 7, e49275. https://doi. org/10.1371/journal.pone.0049275

Crawford SE, Ramani S, Tate JE, Parashar UD, Svensson L, Hagbom M, Franco MA, Greenberg HB, O'Ryan M, Kang G,
Desselberger U, Estes MK (2017): Rotavirus infection. Nat. Rev. Dis. Prim. 3, 17083. https://doi.org/10.1038/ nrdp.2017.83

Fields BN, Knipe DM, Howley PM (2007): Fields Virology. Wolters Kluwer Health/Lippincott Williams \& Wilkins, Philadelphia.

Gadelle D, Bocs C, Graille M, Forterre P (2005): Inhibition of archaeal growth and DNA topoisomerase VI activities by the Hsp90 inhibitor radicicol. Nucleic Acids Res.33, 2310-2317. https://doi.org/10.1093/nar/gki526

Gibert B, Hadchity E, Czekalla A, Aloy MT, Colas P, RodriguezLafrasse C, Arrigo AP, Diaz-Latoud C (2011): Inhibition of heat shock protein 27 (HspB1) tumorigenic functions by peptide aptamers. Oncogene 30,3672 . https:// doi.org/10.1038/onc.2011.73

Graham B, Curry J, Smyth T, Fazal L, Feltell R, Harada I, Coyle J, Williams B, Reule M, Angove H, Cross DM, Lyons J, Wallis NG, Thompson NT (2012): The heat shock protein 90 inhibitor, AT 13387, displays a long duration of action in vitro and in vivo in non-small cell lung cancer. Cancer Sci. 103, 522-527. https://doi.org/10.1111/j.13497006.2011.02191.x

Graham KL, Halasz P, Tan Y, Hewish MJ, Takada Y, Mackow ER, Robinson MK, Coulson BS (2003): Integrin-using rotaviruses bind $\alpha 2 \beta 1$ integrin $\alpha 2$ I domain via VP4 DGE sequence and recognize $\alpha \mathrm{X} \beta 2$ and $\alpha \mathrm{V} \beta 3$ by using VP7 during cell entry. J. Virol. 77, 9969-9978. https:// doi.org/10.1128/JVI.77.18.9969-9978.2003

Gualtero DF, Guzmán F, Acosta O, Guerrero CA (2007): Amino acid domains 280-297 of VP6 and 531-554 of VP4 are implicated in heat shock cognate protein hsc70-mediated rotavirus infection. Arch. Virol.152, 2183-2196. https:// doi.org/10.1007/s00705-007-1055-5

Guerrero CA, Acosta O (2016): Inflammatory and oxidative stress in rotavirus infection. World. J. Virol. 5, 38. https://doi. org/10.5501/wjv.v5.i2.38

Guerrero CA, Bouyssounade D, Zarate S, Isa P, Lopez T, Espinosa R, Romero P, Mendez E, Lopez S, Arias CF (2002) Heat shock cognate protein 70 is involved in rotavirus cell entry. J. Virol. 76, 4096-4102. https://doi.org/10.1128/ JVI.76.8.4096-4102.2002

Guerrero CA, Guerrero RA, Silva E, Acosta O, Barreto E (2016): Experimental adaptation of rotaviruses to tumor cell lines. PLoS One 11, e0147666. https://doi.org/10.1371/ journal.pone.0147666

Guerrero CA, Méndez E, Zárate S, Isa P, López S, Arias CF (2000): Integrin av $\beta 3$ mediates rotavirus cell entry. Proc. Natl. Acad.Sci.USA 97, 14644-14649. https://doi.org/10.1073/ pnas.250299897

Hanson BE, Vesole DH (2009): Retaspimycin hydrochloride (IPI-504): a novel heat shock protein inhibitor as an anticancer agent. Expert. Opin. Investig. Drugs 18, 1375-1383. https://doi.org/10.1517/13543780903158934

Heinrich JC, Tuukkanen A, Schroeder M, Fahrig T, Fahrig R (2011): RP101 (brivudine) binds to heat shock protein HSP27 (HSPB1) and enhances survival in animals and pancreatic cancer patients. J. Cancer Res. Clin. Oncol. 137, 1349. https://doi.org/10.1007/s00432-011-1005-1 
Laederach J, Leodolter J, Warweg J, Weber-Ban E (2014): Designing Drugs Against Hsp90 for Cancer Therapy. In Houry WA (Ed.): The Molecular Chaperones Interaction Networks in Protein Folding and Degradation. Springer, New York, NY, pp. 151-183.

Iša P, Realpe M, Romero P, López S, Arias CF (2004): Rotavirus RRV associates with lipid membrane microdomains during cell entry. Virology 322, 370-381. https://doi. org/10.1016/i.virol.2004.02.018

Kaiser M, Kühnl A, Reins J, Fischer S, Ortiz-Tanchez J, Schlee C, Mochmann LH, Heesch S, Benlasfer O, Hofmann WK, Thiel E, Baldus CD (2011): Antileukemic activity of the HSP70 inhibitor pifithrin- $\mu$ in acute leukemia. Blood Cancer J. 1, e28. https://doi.org/10.1038/bcj.2011.28

Kao CY, Yang PM, Wu MH, Huang CC, Lee YC, Lee KH (2016) Heat shock protein 90 is involved in the regulation of $\mathrm{HM}$ GA2-driven growth and epithelial-to-mesenchymal transition of colorectal cancer cells. PeerJ. 4, e1683. https://doi.org/10.7717/peerj.1683

Lancet JE, Gojo I, Burton M, Quinn M, Tighe SM, Kersey K, Zhong Z, Albitar MX, Bhalla K, Hannah AL, Baer MR (2010): Phase I study of the heat shock protein 90 inhibitor alvespimycin (KOS-1022,17-DMAG) administered intravenously twice weekly to patients with acute myeloid leukemia. Leukemia 24, 699. https://doi.org/10.1038/ leu.2009.292

Lee E, Lee DH (2017): Emerging roles of protein disulfide isomerase in cancer. BMB Rep. 50, 401. https://doi. org/10.5483/BMBRep.2017.50.8.107

Lin C, Xiang G, Zhu X, Xiu LL, Sun JX, Zhang XY (2018): Advances in the mechanisms of action of cancer-targeting oncolytic viruses. Oncol. Lett. 15, 4053-4060. https://doi. org/10.3892/ol.2018.7829

Lin PH, Selinfreund R, Wakshull E, Wharton W (1987): Rapid and efficient purification of plasma membrane from cultured cells: characterization of epidermal growth factor binding. Biochemistry 26(3), 731-736. https://doi. org/10.1021/bi00377a012

Lin T-W, Lo C-W, Lai S-Y, Fan R-J, Lo C-J, Chou Y-M, Thiruvengadam R, Wang A H-J, Wang M-Y (2007): Chicken heat shock protein 90 is a component of the putative cellular receptor complex of infectious bursal disease virus. J. Virol. 81, 8730-8741. https://doi.org/10.1128/ JVI.00332-07

Lopez S, Arias CF (2006): Early steps in rotavirus cell entry. In Reoviruses: Entry, Assembly and Morphogenesis. Curr. Top. Microbiol. Immunol.309, 39-66. https://doi. org/10.1007/3-540-30773-7_2

Massey AJ, Williamson DS, Browne H, Murray JB, Dokurno P, Shaw T, Macias AT, Daniels Z, Geoffroy S, Dopson M, Lavan P, Matassova N, Francis GL, Graham CJ, Parsons R, Wang Y, Padfield A, Comer M, Drysdale MJ, Wood M (2010): A novel, small molecule inhibitor of Hsc70/ Hsp70 potentiates Hsp90 inhibitor induced apoptosis in HCT116 colon carcinoma cells. Cancer Chemother. Pharmacol. 66, 535-545. https://doi.org/10.1007/ s00280-009-1194-3
Mulgrew K, Kinneer K, Yao X-T, Ward BK, Damschroder MM, Walsh B, Mao S-Y, Gao C, Kiener PA, Coats S, Kinch MS, and Tice DA (2006): Direct targeting of $\alpha v \beta 3$ integrin on tumor cells with a monoclonal antibody, AbegrinTM. Mol. Cancer Ther. 5, 3122-3129. https:// doi.org/10.1158/1535-7163.MCT-06-0356

Nadeau K, Nadler SG, Saulnier M, Tepper, MA, Walsh CT (1994): Quantitation of the interaction of the immunosuppressant deoxyspergualin and analogs with Hsc70 and Hsp90. Biochemistry 33, 2561-2567. https://doi. org/10.1021/bi00175a027

Nagai N, Nakai A, Nagata K (1995): Quercetin suppresses heat shock response by down-regulation of HSF1. Biochem. Biophys. Res. Commun. 208, 1099-1105. https://doi. org/10.1006/bbrc.1995.1447

O'Brien J, Wilson I, Orton T, Pognan F (2000): Investigation of the Alamar Blue (resazurin) fluorescent dye for the assessment of mammalian cell cytotoxicity. Eur. J. Biochem./ FEBS. 267(17),5421-5426. https://doi.org/10.1046/j.1432$\underline{1327.2000 .01606 . x}$

Ohnishi K, Takahashi A, Yokota S, Ohnishi T (2004): Effects of a heat shock protein inhibitor KNK437 on heat sensitivity and heat tolerance in human squamous cell carcinoma cell lines differing in p53 status. Int. J. Radiat. Biol. 80, 607-614. https://doi.org/10.1080/0955 $\underline{3000412331283470}$

Pan B, Guo J, Liao Q, Zhao Y (2018): $\beta 1$ and $\beta 3$ integrins in breast, prostate and pancreatic cancer: A novel implication. Oncol. Lett. 15, 5412-5416. https://doi.org/10.3892/ $\underline{\text { ol.2018.8076 }}$

Raja J, Ludwig JM, Gettinger SN, Schalper KA, Kim HS (2018): Oncolytic virus immunotherapy: future prospects for oncology. J. Immunother. Cancer 6, 140. https://doi. org/10.1186/s40425-018-0458-z

Ramos FS, Serino LT, Carvalho CM, Lima RS, Urban CA, Cavalli IJ, Ribeiro EMSF (2015): PDIA3 and PDIA6 gene expression as an aggressiveness marker in primary ductal breast cancer. Genet. Mol. Res. 14, 6960-6967. https:// doi.org/10.4238/2015.June.26.4

Reyes-del Valle J, Chávez-Salinas S, Medina F, Del Angel RM (2005): Heat shock protein 90 and heat shock protein 70 are components of dengue virus receptor complex in human cells. J. Virol. 79, 4557-4567. https://doi. org/10.1128/JVI.79.8.4557-4567.2005

Robinson SD, Hodivala-Dilke KM (2011): The role of $\beta 3$-integrins in tumor angiogenesis: context is everything. Curr. Opin. Cell. Biol. 23, 630-637. https://doi.org/10.1016/j. ceb.2011.03.014

Rodina A, Vilenchik M, Moulick K, Aguirre J, Kim J, Chiang A, Litz J, CC, Kang Y, She Y, Wu N, Felts S, Wipf P, Massague J, Jiang X, Brodsky JL, Krystal GW, Chiosis G (2007): Selective compounds define Hsp90 as a major inhibitor of apoptosis in small-cell lung cancer. Nat. Chem. Biol. 3, 498. https://doi.org/10.1038/nchembio.2007.10

Rong Y, Yang EB, Zhang K, Mack P (2000): Quercetin-induced apoptosis in the monoblastoid cell line U937 in vitro and the regulation of heat shock proteins expression. Anticancer Res. 20(6B), 4339-4345. 
Rui Y, Qiusha T, Fengqin M, Yanli A, Li M, Yong H, Wang X, Wang J, Liu P, Chen R (2015): Inhibition of heat-shock protein 90 sensitizes liver cancer stem-like cells to magnetic hyperthermia and enhances anti-tumor effect on hepatocellular carcinoma-burdened nude mice. Int. J. Nanomedicine 10,7345-7358. https://doi.org/10.2147/ $\underline{\text { IJN.S93758 }}$

Salamanca HH, Antonyak MA, Cerione RA, Shi H, Lis JT (2014): Inhibiting heat shock factor 1 in human cancer cells with a potent RNA aptamer. PLoS One 9, e96330. https://doi.org/10.1371/journal.pone.0096330

Santagata S, Mendillo ML, Tang Y, Subramanian A, Perley CC, Roche SP, Wong B, Narayan R, Kwon H, Koeva M, Amon A, Golub TR, Porco JA, Whitesell L, Lindquist S (2013): Tight coordination of protein translation and HSF1 activation supports the anabolic malignant state. Science 341, 250-260. https://doi.org/10.1126/ science. 1238303

Schlecht R, Scholz SR, Dahmen H, Wegener A, Sirrenberg C, Musil D, Bomke J, Hans-Eggenweiler M, Mayer MP, Bukau B (2013): Functional Analysis of Hsp70 Inhibitors. PLoS One 8(11), e78443. https://doi.org/10.1371/ journal.pone.0078443

Seigneuric R, Gobbo J, Colas P, Garrido C (2011): Targeting cancer with peptide aptamers. Oncotarget 2,557 . https://doi. org/10.18632/oncotarget.297

Sivanandam V, LaRocca CJ, Chen NG, Fong Y, Warner SG (2019): Oncolytic Viruses and Immune Checkpoint Inhibition: The Best of Both Worlds. Mol. Ther. Oncolytics. 13, 93. https://doi.org/10.1016/i.omto.2019.04.003

Soga S, Shiotsu Y, Akinaga S, Sharma SV (2003): Development of radicicol analogues. Curr. Cancer Drug Targets. 3, 359-369. https://doi.org/10.2174/1568009033481859

Stangl S, Gehrmann M, Riegger J, Kuhs K, Riederer I, Sievert W, Hube K, Mocikat R, Dressel R, Kremmer E, Pockley AG, Friedrich L, Vigh L, Skerra A, Multhoff G (2011): Targeting membrane heat-shock protein 70 (Hsp70) on tumors by cmHsp70. 1 antibody. Proc. Natl. Acad. Sci. USA 108, 733-738. https://doi.org/10.1073/ pnas. 1016065108

Strober W (2001): Trypan blue exclusion test of cell viability. Curr. Protoc. Immunol. Appendix 3:Appendix 3B. https://doi.org/10.1002/0471142735.ima03bs21

Su T, Lin J, Chiu C, Yi J, Jui FC, Zhi HS, Wen JC, Hwang I, Hsiang $\mathrm{H} \mathrm{H}, \mathrm{Wu}$ Y-J (2012): Proteomic investigation of antitumor activities exerted by sinularin against A 2058 melanoma cells. Electrophoresis 33,1139-1152. https:// doi.org/10.1002/elps.201100462

Ueno T, Tsukuda K, Toyooka S, Andoa M, Takaoka M, Soh J, Asano H, Maki Y, Muraoka T, Tanaka N, Shien K, Furukawa M, Yamatsuji T, Kiura K, Naomoto Y, Miyoshia S (2012): Strong anti-tumor effect of NVP-AUY922, a novel Hsp90 inhibitor, on non-small cell lung cancer. Lung Cancer 76, 26-31. https://doi.org/10.1016/j.lungcan.2011.09.011

Uyy E, Suica VI, Boteanu RM, Manda D, Baciu AE, Badiu C, Antohe F (2016): Endoplasmic reticulum chaperones are potential active factors in thyroid tumorigenesis. J. Proteome Res. 15, 3377-3387. https://doi.org/10.1021/ acs.jproteome.6b00567

Vansteenkiste J, Barlesi F, Waller CF, Bennouna J, Gridelli C, Goekkurt E, Verhoeven D, Szczesna A, Feurer M, Milanowski J, Germonpre P, Lena H, Atanackovic D, Krzakowski M, Hicking C, Straub J, Picard M, Schuette W, O'Byrne K (2015): Cilengitide combined with cetuximab and platinum-based chemotherapy as first-line treatment in advanced non-small-cell lung cancer (NSCLC) patients: results of an open-label, randomized, controlled phase II study (CERTO). Ann. Oncol. 26,1734-1740. https://doi.org/10.1093/annonc/mdv219

Wang X, Chen M, Zhou J, Zhang X (2014): HSP27, 70 and 90, antiapoptotic proteins, in clinical cancer therapy. Int. J. Oncol. 45, 18-30. https://doi.org/10.3892/ijo.2014.2399

Wiechmann K, Müller H, König S, Wielsch N, Svatoš A, Jauch J, Werz O (2017): Mitochondrial chaperonin HSP60 is the apoptosis-related target for myrtucommulone. Cell Chem. Biol. 24, 614-623. https://doi.org/10.1016/i. chembiol.2017.04.008

Wu J, Liu T, Rios Z, Mei Q, Lin X, Cao S (2017): Heat shock proteins and cancer. Trends Pharmacol. Sci. 38, 226-256. https://doi.org/10.1016/j.tips.2016.11.009

Xu T, Lin Z, Wang C, Li Y, Xia Y, Zhao M, Hua L, Chen Y, Guo M, Zhu B(2019): Heat shock protein 70 as a supplementary receptor facilitates enterovirus 71 infections in vitro. Microb. Pathog. 128, 106-111. https://doi.org/10.1016/j. micpath.2018.12.032

Xu X, Wei X, Ling Q, Cheng J, Zhou B, Xie H, Zhou L, Zheng S (2011): Identification of two portal vein tumor thrombosis associated proteins in hepatocellular carcinoma: Protein disulfide-isomerase A6 and apolipoprotein A-I. J. Gastroenterol. Hepatol.26, 1787-1794. https://doi. org/10.1111/i.1440-1746.2011.06796.x

Yang X, Tohda C (2018): Heat shock cognate 70 inhibitor, VER-155008, reduces memory deficits and axonal degeneration in a mouse model of Alzheimer's disease. Front. Pharmacol. 9, 48. https://doi.org/10.3389/ fphar.2018.00048

Yoon YJ, Kim JA, Shin KD, Shin D-S, Han YM, Lee YJ, Lee JS, Kwon B-M, Hant DC (2011): KRIBB11 inhibits HSP70 synthesis through inhibition of heat shock factor 1 function by impairing the recruitment of positive transcription elongation factor $\mathrm{b}$ to the hsp70 promoter. J. Biol. Chem. 286, 1737-1747. https://doi.org/10.1074/ jbc.M110.179440

Zárate S, Espinosa R, Romero P, Guerrero CA, Arias CF, López $S$ (2000) Integrin $\alpha 2 \beta 1$ mediates the cell attachment of the rotavirus neuraminidase-resistant variant nar3. Virology 278, 50-54. https://doi.org/10.1006/ viro.2000.0660

Zárate S, Romero P, Espinosa R, Arias CF, López S (2004) VP7 mediates the interaction of rotaviruses with integrin av $\beta 3$ through a novel integrin-binding site. J. Virol. 78, 10839-10847. https://doi.org/10.1128/JVI.78.20.10839$\underline{10847.2004}$ 
Zhang FZ, Ho DH-H, Wong RH-F (2018): Triptolide, a HSP90 middle domain inhibitor, induces apoptosis in triple manner. Oncotarget 9, 22301-22315. https://doi. org/10.18632/oncotarget.24737x

Zhu Y-Z, Cao M-M, Wang W-B, Wang W, Ren H, Zhao P, Qi Z-T (2012): Association of heat-shock protein 70 with lipid rafts is required for Japanese encephalitis virus infec- tion in Huh7 cells. J. Gen. Virol. 93, 61-71. https://doi. org/10.1099/vir.0.034637-0

Zong J, Guo C, Liu S, Sun M-Z, Tang J (2012): Proteomic research progress in lymphatic metastases of cancers. Clin. Transl. Oncol.14,21-30. https://doi.org/10.1007/s12094$\underline{012-0757-7}$ 